\title{
EX PARTE COMMUNICATIONS IN OFF-THE- \\ RECORD ADMINISTRATIVE \\ PROCEEDINGS: A PROPOSED \\ LIMITATION ON \\ JUDICIAL INNOVATION
}

\author{
GlenN T. CARberRY*
}

I. IntRoduction.................................... 66

II. A FRAMEWORK FOR ANALYSIS................... 70

A. Judicial and Legislative Models of Decisionmaking .... 70

B. Judicial Approaches to Ex Parte Communications in Offthe-Record Proceedings .......................... 74

C. Summary ................................. 79

III. Statutory and Constitutional ARguments for ProHIBITING EX PARTE CoMmunICATIONS ............... 80

A. Implied Congressional and Executive Mandate ....... 80

B. Meaningful Public Participation ................. 83

1. Section 553(c) of the Administrative Procedure Act

2. Statutory Hearing Provisions ................ 85

C. Requirements of Judicial Review ................. 88

1. Administrative Record ...................... 89

2. Effective Judicial Review .................... 92

3. Improper Judicial Innovations................. 94

D. Due Process ................................. 98

1. The Applicability of Due Process.............. 98

2. Ex Parte Communications and Due Process....... 99

IV. Conclusions ........................................ 101

* B.A. 1976, Gettysburg College; J.D. 1979, University of Pennsylvania Law School; Associate, Hogan \& Hartson, Washington, D.C.

THE FOLLOWING CITATIONS WILL BE USED IN THIS ARTICLE:

K. Davis, Administrative Law Treatise (2d ed. 1978 \& 1979) [hereinafter cited as K. DAVIS, TREATISE];

Auerbach, Informal Rule Making: A Proposed Relationship Between Administrative Procedures and Judicial Review, 72 Nw. U.L. Rev. 15 (1977) [hereinafter cited as Auerbach];

Nathanson, Report to the Select Committee on Ex Parte Communications in Informal Rulemaking Proceedings, 30 AD. L. REv. 377 (1978) [hereinafter cited as Nathanson];

Comment, Ex Parte Communications in Rulemaking: Hoine Box Office and Action for Children's Television, 1978 ARIz. ST. L.J. 69 [hereinafter cited as Comment, ARIz. ST. L.J.]. 


\section{INTRODUCTION}

The permissibility of ex parte communications ${ }^{1}$ by interested persons during "off-the-record"' agency proceedings has been the subject of considerable controversy in recent years. In the past, Congress, the courts, and governmental agencies have agreed that the justifications for prohibiting ex parte communications applied only to adjudicatory proceedings governed by sections 554, 556, and 557 of the Administrative Procedure $\mathrm{Act}^{3}$ or to other agency proceedings involving the "resolution of conflicting private claims to a valuable privilege."4 In 1977,

1. Ex parte communications, as defined by the Administrative Procedure Act, include "oral or written communication[s] not on the public record with respect to which reasonable prior notice to all parties is not given, . . . [but do not include] requests for status reports . . ." 5 U.S.C. § 551(14) (1976). The Government in the Sunshine Act, 5 U.S.C. § 557(d) (1976), narrowed this definition somewhat by prohibiting only those ex parte communications that are "relevant to the merits." 5 U.S.C. \& 557(d)(1)(A)-(B) (1976).

In practice ex parte communications take a variety of forms. See, e.g., Hercules Inc. v. EPA, 598 F.2d 91 (D.C. Cir. 1978) (intra-agency discussions between the EPA's chief judicial officer and agency experts regarding the record); United States Lines, Inc. v. Federal Maritime Comm'n, 584 F.2d 519 (D.C. Cir. 1978) (receipt of additional information by the Commission staff froin one party and two foreign governments after the close of the notice and comment period); Action for Children's Television v. FCC, 564 F.2d 458 (D.C. Cir. 1977) (private neetings between representative of the broadcast industry and Chairman of the FCC); Home Box Office, Inc. v. FCC, 567 F.2d 9 (D.C. Cir.) (private neetings between FCC Commissioner and industry representatives to the exclusion of public interest intervenors, and indirect ex parte communications through congressional pressure), cert. denied, 434 U.S. 829 (1977); District of Columbia Fed'n of Civic Ass'ns v. Volpe, 459 F.2d 1231 (D.C. Cir. 1971) (public threats by several congressmen to withhold agency appropriations), cert. denied, 405 U.S. 1030 (1972).

2. As used here, the term "off-the-record" proceeding means any agency decisionmaking process that is not an adjudication or a rulenraking proceeding required to be held "on-the-record" under the Administrative Procedure Act.

3. 5 U.S.C. $\S \S 554,556,557$ (1976). The original Administrative Procedure Act prohibited ex parte contacts during any adjudication proceeding. 5 U.S.C. $\$ 554$ (d) (1970). In addition, section 556(e) effectively barred agency decisionmakers from receiving ex parte communications during formal rulemaking proceedings by stating that the hearing transcript and written subunissions fron the parties should constitute "the exclusive record for decision." See 46 Geo. WASH. L. REv. 442, $448 \mathrm{n} .42$ (1978). Neither of these provisions, however, applied to "the agency or a meinber or members of the body conprising the agency." 5 U.S.C. \& 554(d)(C) (1970).

Congress clarified the law governing ex parte communications in the Government in the Sunshine Act, Pub. L. No. 94-409, 90 Stat. 1246 (1976) (codified at 5 U.S.C. § 557(d) (1976)). This 1976 ainendnient to the Administrative Procedure Act expressly prohibited ex parte communications on the merits in all fornal agency proceedings between an interested person and any agency official "who is or may reasonably be expected to be involved in the decisional process." 5 U.S.C. $\S 557(d)(1)(A)$ (1976). If a communication is received by the agency, it must be sumnnarized and placed in the public record of the proceeding. Id. $\S 557(\mathrm{~d})(1)(\mathrm{C})$.

4. Sangamon Valley Television Corp. v. United States, 269 F.2d 221, 224 (D.C. Cir. 1959). The underlying rationale of the Sangamon Valley case was that undisclosed ex parte communications are permissible in infornal rulemakings as long as the proceeding does not involve a factual dispute between distinct parties over a valuable privilege. This principle governed the legality of ex parte communications in off-the-record proceedings for almost two decades. For a unore complete discussion of Sangamon Valley, see text accompanying notes 57-61 infra. 
however, the Court of Appeals for the District of Columbia questioned these assumptions in Home Box Office, Inc. v. FCC 5 and ordered a comprehensive prohibition against ex parte commumications on the merits in all rulemaking proceedings. Although the District of Columbia Circuit in Action for Children's Television v. $F C C^{6}$ retreated from an absolute ban on ex parte communications and reasserted a case-by-case approach based on traditional standards, distinctions between the two cases ensured the continuing vitality of the Home Box Office rule. ${ }^{7}$

Three 1978 decisions of the District of Columbia Circuit further demonstrated the willingness of the court to scrutinize off-the-record agency proceedings for improper ex parte communications. ${ }^{8}$ First, in United States Lines, Inc. v. Federal Maritime Commission, ${ }^{9}$ the court held that the Federal Maritime Commission improperly relied on undisclosed ex parte communications in a quasi-adjudicatory proceeding that approved an amendment to a joint service agreement between two ocean carriers and granted an exemption from the antitrust laws. The court reasoned that informal agency adjudications should be governed

5. 567 F.2d 9 (D.C. Cir.), cert. denied, 434 U.S. 829 (1977).

6. 564 F.2d 458 (D.C. Cir. 1977).

7. In Home Box Office, the Federal Communications Commission had developed a rule that "conferred preferential advantages on vast segments of the broadcast industry to the detriment of other coinpeting business interests," 567 F.2d at 62 (MacKinnon, J., concurring specially), and was thus at least arguably within the scope of the Sangamon Valley doctrine. See note 4 supra. The Action for Children's Television case is distinguishable on three grounds. First, the proceeding in Action for Children's Television did not result in the formulation of a rule. Second, there was no indication that the Federal Communications Commission gave any of the interested parties in Action for Children's Television any advantages not shared by all. Third, the Action for Children's Television proceeding was classic informal rulemaking involving the fornulation of policy revisions of general applicability.

8. In still another case, the District of Columbia District Court also held that undisclosed ex parte commumications were improper in off-the-record agency proceedings. Environmental Defense Fund, Inc. v. Blum, 458 F. Supp. 650 (D.D.C. 1978). In Blum the district court remanded a final order of the Environmental Protection Agency granting the State of Mississippi an exemption from the registration requirements of the Federal Insecticide, Fungicide, and Rodenticide Act, 7 U.S.C. $\S \S 136-136 y$ (1976). The court held that the Agency had violated section 553 of the Administrative Procedure Act by receiving ex parte communications from imterested parties after the formal closing of the record in an informal rulemaking proceeding. Expressly applying Home Box Office, Action for Children's Television, and United States Lines, Inc. v. Federal Maritime Comun'n, 584 F.2d 519 (D.C. Cir. 1978), to the proceeding before it, the court remarked: "Where ... the information received ex parte is not generated internally by the agency, bears directly on highly complex technical issues, and will probably have some effect on the final outcome, it should be revealed for public comment before the agency reaches its decision." $458 \mathrm{~F}$. Supp. at 660 .

In a number of other circuit court cases ex parte cominunications were not held to be improper because an examination of the facts demonstrated that the parties were not prejudiced in any way. See Rogers Radio Comınunication Servs., Inc. v. FCC, 593 F.2d 1225, 1233-34 (D.C. Cir. 1978); Hawaiian Tel. Co. v. FCC, 589 F.2d 647, 654 n.13 (D.C. Cir. 1978); Western Union Int'l, Inc. v. FCC, 568 F.2d 1012, 1019 (2d Cir. 1977), cert. denied, 436 U.S. 944 (1978).

9. 584 F.2d 519 (D.C. Cir. 1978). 
by the same standards applied to notice and comment rulemaking im Home Box Office ${ }^{10}$ and advanced three bases for holding that ex parte communications were illegal: (1) the commumications foreclosed effective judicial review of the agency's final decision under the Administrative Procedure Act's "arbitrary and capricious" standard of review; (2) the communications violated the principles of fairness inherent in constitutional due process; and (3) the communications were inconsistent with the public's right under the Shipping Act of $1916^{11}$ to ineaningful participation in the Federal Maritime Cominission's decisionmaking process through a "liearing" prior to agency action.12

In National Small Shipments Traffic Conference, Inc. v. ICC, ${ }^{13}$ the District of Columbia Circuit used similar reasoning in holding that the Interstate Commerce Commission's receipt of ex parte communications in an "informal ruleniaking" proceeding necessitatcd a full remand to the agency. Even though the focus of the proceeding was on the "validity of certain rate-1naking primciples . . . that future rate-nıaking would depend on," 14 rather than on the reasonableness of previously enacted rates, the court argued that "tlle adjudication contemplated in this case lies near the core described by the [ex parte communications] doctrime's rationales."15

Finally, in Hercules Inc. v. EPA, ${ }^{16}$ the court declined to prohibit undisclosed intra-agency staff contacts with agency decisionmakers in a notice and comment rulemaking proceeding lield prior to the Home Box Office decision. The court left open the possibility that the primciples underlying Home Box Office would require the prohibition of intra-agency contacts in other cases. ${ }^{17}$

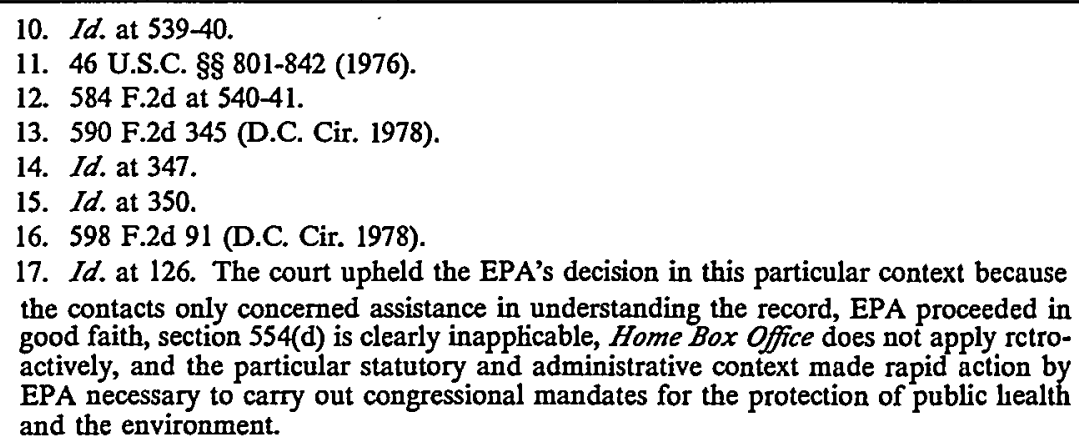

Id. at 127. The District of Columbia Circuit's position on intra-agency ex parte commumcations remains unclear in light of the Hercules decision and the court's recent opinion in Association of Nat'l Advertisers, Inc. v. FTC, 1979-2 Trade Cas. I 62,950, at 79,394 (D.C. Cir. 1979). In the National Advertisers case the court held that it would be "inappropriate if not impossible to decide whether the proscription on ex parte contacts outlined in Home Box Office and other cases," Id. at 79,399 , apphed to contacts between FTC Commissioners and their geueral staff when the nature of the contacts was a matter of speculation and the case was currently unsuitable for judicial 
Despite the District of Columbia Circuit's firm commitment to a strict ex parte communications doctrine, the debate ${ }^{18}$ surrounding the subject is likely to contimue for several reasons. First, the Supreme Court expressly disapproved of any judicially imposed procedural innovations in Vermont Yankee Nuclear Power Corp. v. National Resources Defense Council, Inc. ${ }^{19}$ Second, congressional leaders and the Administration declined to restrict ex parte communications im off-therecord proceedings in the proposed comprehensive "Regulation Reforin Act of 1979."20 Third, executive and independent regulatory agencies have reacted cautiously to the District of Columbia Circuit's policy by proposing or adopting rules that impose a variety of restrictions on ex parte communications with their members. ${ }^{21}$

This Article will examine the validity of the District of Columbia Circuit's approach to ex parte communications in off-the-record proceedings. It begins with a theoretical discussion of the compatability of ex parte communications with the judicial and legislative inodels of

resolution. Id. at 79,399-400. Further, Judge Wright stated in a concurring opinion that a prohibition of possible ex parte communications in a trade regulation rulemaking on children's advertising was unjustified despite appellant's attempt to characterize the proceeding as an adjudication or adversarial process because the law in the circuit was "unsettled" on the inatter. Id. at 79,40506, (Wright, J., concurring in the result). Compare Action for Children's Television v. FCC, 564 F.2d 458, 471 n.22 (D.C. Cir. 1977) with Hone Box Office, Inc. v. FCC, 567 F.2d 9, 55 (D.C. Cir.), cert. denied, 434 U.S. 829 (1977).

18. Scholars and law review commentators have discussed the holdings of Home Box Office and Action for Children's Television in great detail. See Bruff, Presidential Power and Administrative Rulemaking, 88 Y ALE L.J. 451, 500-06 (1979); Nathanson; Comment, ARIZ. ST. L.J.; Note, Ex Parte Contacts in Informal Rulemaking, 65 CAL. L. Rev. 1315 (1977); Note, Ex Parte Contacts in Informal Rulemaking: Home Box Office and Action for Children's Television v. FCC, 57 NEB. L. Rev. 843 (1978); 46 Geo. WASH. L. Rev., supra note 3.

19. 435 U.S. 519 (1978).

20. S. 755, 96th Cong., Ist Sess., 125 CoNG. REc. S3337 (daily ed. Mar. 26, 1979).

21. See, e.g., 14 C.F.R. \& 300.2-3 (1978) (CAB) (prohibiting substantive communications regarding a public proceeding between any concerned Board employee and any nonemployee, and requiring disclosure on the public record); 16 C.F.R. \& 1.18(c) (1978) (FTC) (prohibiting ex parte commnnications and requiring disclosure of their contents whenever they occur in hybrid rulemnaking under the Magnuson-Moss Act, 15 U.S.C. $\$ \S 45,46,49,50,52,56,57 a-57 c, 2301-2312$ (1976)); 16 C.F.R. \& 1012.2(g) (1978) (CPSC) (requiring all agency "meetings" to be open to the public with advance notice and requiring all communications with the agency in rulemaking proceedings to be summarized and placed on the public file). For a detailed discussion of these rules and other agency ex parte guidelines, see Comment, ARIZ. ST. L.J. 87-94.

The Administrative Conference urged that agencies log all ex parte communications and place them in a file for public inspection. 1 C.F.R. $\$ 305.77-3$ (1978). See also 10 C.F.R. $§ 204$ (1978) (FEA); DOT Order 2100.2, Oct. 5, 1970. In contrast, the Federal Commnnications Coininission reacted conservatively to Home Box Office and Action for Children's Television, refusing to prohibit ex parte communications in any proceeding other than those of a qnasi-adjudicatory nature and experimenting with procedures for the disclosure of communications in other proceedings. This interim pohicy was later withdrawn because of adverse public comment. $43 \mathrm{Fed}$. Reg. 27,868 (1978). 
decisionmaking that underlie the administrative system. The Article argues that altlough a judicial model of decisionmaking requires the prohibition of ex parte communications, this model slould rarely be applied to off-the-record agency proceedings due to the distinctive purposes of administrative action. ${ }^{22}$ Following this overview of the problem, the Article reviews the court's changing approacl to ex parte communications in off-tlee-record proceedings, identifying the analytical themes and distinctions that liave been relied upon by the court to determine the resolution of particular cases. ${ }^{23}$

The focus of the Article then shifts to the statutory and constitutional arguments offered by the District of Colunnbia Circuit to justify its approaclı to ex parte communications. ${ }^{24}$ First, the Article analyzes the argunient tliat ex parte communications conflict witli implied congressional and Administration policies, ${ }^{25}$ the public's riglit to participate in agency decisionmaking under the Administrative Procedure Act and various governing statutes, ${ }^{26}$ and the court's need to preserve effective judicial review of agency decisions. ${ }^{27}$ Acknowledging the legitimacy of some of the court's concerns, the Article nevertheless concludes that the court slould refrain from imposing an additional procedural safeguard on off-tlie-record agency proceedimgs because the relevant statutory provisions do not require the prohibition or disclosure of ex parte communications. ${ }^{28}$ Finally, the Article considers the court's contention tlat ex parte communications are inherently unfair and violative of due process. ${ }^{29}$ Rejecting this constitutional theory, the Article argues that agencies are not limited by due process in exercising their discretion to receive ex parte communications without disclosure in off-the-record proceedings, unless establislied judicial doctrines indicate that the proceeding is sufficiently adjudicative to mvoke additional constitutional protection.

\section{A FRAMEWORK FOR ANALYSIS}

\section{A. Judicial and Legislative Models of Decisionmaking.}

The administrative process has been defined as a collection of the law-making and law-deciding powers that are exercised by government

\footnotetext{
22. See notes $30-47$ infra and accompanying text.

23. See notes $48-84$ infra and accoinpanying text.

24. See notes 85-237 infra and accompanying text.

25. See notes 85-113 infra and accompanying text.

26. See notes 114-44 infra and accompanying text.

27. See notes 145-214 infra and accompanying text.

28. See notes 187-214 infra and accompanying text.

29. See notes 215-37 infra and accompanying text.
} 
entities within the executive branch instead of by the legislature or the court system. ${ }^{30}$ Although administrative decisionmaking is intended to be unique, the standards and practices of judicial and legislative decisionmaking often provide the parameters within which administrative agencies operate.

The application of judicial and legislative models of decisionmaking to the issue of ex parte communications provides a theoretical frainework for determining the types of administrative proceedings in which ex parte communications should be prohibited. If an agency proceeding is characterized primarily as a judicial inquiry, then the applicability of a judicial model of decisionmaking would require the prohibition and disclosure of all ex parte communications. Ex parte communications are unquestionably incompatible with the concept of a fair trial-type hearing. ${ }^{31}$

In contrast, when an agency proceeding is primarily a legislative process, ex parte communications should not be prohibited. Congressinen have traditionally been free to seek information and to provide informal access to constituents and lobbyists. Rather than diminishing the importance of public discussion of a bill in open committee hearings and floor debate, these additional information sources supplement a congressinan's knowledge, thereby increasing the likelihood of an informed and reasoned decision. The saine principle may apply to discretionary private discussions and conferences by agency decisionmakers engaged in ruleinaking or other informal actions. Agency commissioners must have the flexibility to gather knowledge regarding questions before the regulatory agency. ${ }^{32}$ As one former cominissioner reinarked:

A member of a regulatory agency as they $[$ sic $]$ are constituted today cannot possibly decide a case solely on the record before him. A man who has the duty of promoting the welfare of an industry must learn all he can about that industry. He must read books, magazines, reports. He must see the industry firsthand as much as possible. He inust talk with executives and employees involved in all phases of industry operations, he must talk with the public, with customers and patrons of the imdustry. He must as best as he can inform himself of

30. See L. JafFe \& N. Nathanson, Administrative Law 10 (1976).

31. See, e.g., ABA CODE OF Judicial Conduct Canon 3(A)(4) \& Commentary; Hearings on H.R. 10315 \& 9868 Before the House Comm. on Government Operations, 94th Cong., 1st Sess. 248 (1975) (noting that finding an advocate for ex parte communications in formal trial-type proceedings is like "finding an advocate for sin").

32. See, e.g., 1 C.F.R. $§ 305.77-3$ (1978) (Administrative Conference Recommendation No. 77-3); K. Davis, Administrative LaW OF THE SeVEnTies § 6:18, at 537 (1976); Peck, Regulation and Control of Ex Parte Communications with Administrative Agencies, 76 HARv. L. REv. 233 (1962). 
the impact of the industry's operations on our national economy and our national defense. ${ }^{33}$

This analysis indicates that no theoretical foundation exists for a comprehensive ban on ex parte communications in all agency proceedings. If, regardless of the character of the proceedings, adıninistrative decisionmakers are forced to assuine the posture of judges rather than specialized experts, the peculiar advantages of the administrative system are diminished and original congressional justifications for delegating judicial and legislative powers to the agencies are undermined. ${ }^{34}$ The problem, therefore, is to identify the administrative proceedings that inerit the apphication of a judicial model..$^{35}$

The Administrative Procedure Act does not address the issue of appropriate administrative procedures in terms of separate legislative and judicial functions. Instead, the Act creates two categories of procedural requirements for administrative actions. The trial-type hearing provisions of sections 554, 556, and $557^{36}$ apply to agency adjudications and to any ruleinaking proceeding in which the governing statute specifies that rules be promulgated "on the record after opportunity for an agency hearing ...."37 In contrast, the legislative-type notice and comment provisions of section 553 apply to all rulemaking proceedings that are not required to be held "on the record" and to other informal agency actions. ${ }^{38}$

33. Hearings on S. Res. 234 Before the Subcomm. on Adminisirative Practice and Procedure of the Senate Comm. on the Judiciary, 86th Cong., 2d Sess. 239 (1960) (statement of former CAB Commissioner Louis Hector).

34. Although the problem of agency deference' to the interests of regulated industries is well established, see Home Box Office, Inc. v. FCC, 567 F.2d 9, 53 (D.C. Cir.), cert. denied, 434 U.S. 829 (1977), there is a point at which the public must rely upon trust if the administrative system is to continue functioning effectively and attracting competent individuals to public sérvice positions.

35. One scholar phrased the issue as follows: "No one will quarrel with the position that improper ex parte communications should be prohibited. But no one will contend that all ex parte communications are improper. So the real question is . . . where to draw the line." Stone, $E x$ Parte Communications: The Harris Bill, the CAB, and the Dilemma of Where to Draw the Line, 13 AD. L. REv. 141, 141 (1960) (emphasis in original).

36. 5 U.S.C. $\S \S 554,556,557$ (1976). Agency hearings governed by these provisions are similar to judicial proceedings. Opposing parties, often a private firm and the agency trial staff, create a formal record through an adversary process before an administrative law judge or an agency member. As long as the agency does not decide to adopt procedures for the submission of written evidence, the parties are entitled to present their views by oral or documentary evidence, to rebut evidence, and to conduct cross-examination.

37. Id. $\$ 554(a)$.

38. Id. $\S 553$. Proceedings subject to the notice and comment requirements of section 553 must follow three main steps. First, the agency must publish a general notice of the proposcd rulenaking in the Federal Register, describing the terms of the rule, its legal foundations, and the subjects and issues involved. Second, following the notice, the agency must allow interested persons to participate in the rulemaking through the submission of written data, views, or arguments. 
These statutory provisions, in combination with the Act's broad definition of an agency rule, ${ }^{39}$ create a false dichotomy that allows administrative decisions involving disputed factual and legal issues between distinct parties to be governed by the same procedures applicable to decisions settmg forth broad policy guidelines. This confusion is illustrated by examining two different sorts of proceedings ${ }^{40}$ that the Administrative Procedure Act would place in the same "off-tlie-record" category. For example, when an agency is engaged in traditional informal notice and comment rulemaking, the issues are complex and numerous, the parties are diverse and unalignable, and the agency's nonaccusatory decision requires the discretionary implementation of statutory policy and an assessment of future consequences. ${ }^{41}$ This type of off-the-record proceeding clearly is unsuited to trial-type procedures, since it involves the weighing of "legislative facts." 42 Although informal administrative rulemaking is not directly analogous to legislation, ${ }^{43}$ the process resembles the enactment of a statute. ${ }^{44}$ Moreover, the purpose of these proceedings is not to try a case in an administrative court, but to inform the agency and to protect affected interests

Third, the agency must consider the matter presented and publish a final rule mcorporating a general statement of the rule's basis and purpose. Id.

In practice the courts have supplemented the notice and comment provisions of section 553 by requiring additional procedures. Auerbach 16; Pedersen, The Decline of Separation of Functions in Regulatory Agencies, 64 VA. L. REv. 991, 1016 (1978); Wright, The Courts and the Rulemaking Process: The Limits of Judicial Review, 59 CoRnell L. Rev. 375, 378 (1974). Similarly, Congress has legislated procedural protections beyond those required by due process or the Admimistrative Procedure Act in many regulatory statutes. See Hamilton, Procedures for the Adoption of Rules of General Applicability: The Need for Procedural Innovation in Administrative Rulemaking, 60 CAL. L. REv. 1276, 1277 (1972).

39. The Administrative Procedure Act defines a rule as "the whole or a part of an agency statement of general or particular applicability and future effect, designed to implement, interpret, or prescribe law or policy ...." 5 U.S.C. $\$ 551$ (4) (1976) (emphasis added).

40. The difficulty of using the definition of the Administrative Procedure Act to identify the category of proceedings in which ex parte communications should be regulated has long been recognized. See, e.g., Peck, supra note 32, at 239-43.

41. Attorney General's Committee on Administrative Procedure, final Report, S. Doc. No. 8, 77th Cong., 1st Sess. 109-10 (1941).

42. $2 \mathrm{~K}$. Davis, TREaTise $\S 7: 2$. Davis's traditional focus on the nature of the facts at issue in a proceeding does not directly follow the mode of analysis used in this Article, which concentrates on the nature of the decision made by the agency. Nevertheless, the position taken here-that most rulemakings are primarily legislative inquiries-is firmly supported by Davis's observation that "facts in a notice and comment proceeding should be deeined legislative facts, because their primary purpose is to determine the content of law or pohicy or to decide what course of action to take." 1 Id. § 6:17, at 529.

43. See Comment, ARIz. ST. L.J. 72. The author argues that agency ruleinaking differs from legislation in that agency discretion is limited by statute, the agency is not directly accountable to the public, and the issues under consideration often reseinble adjudication.

44. 2 K. Davis, Treatise $\$ 7: 2$, at 4. 
against uninformed or unwise action. ${ }^{45}$ Under these circumstances, the assumption that agency decisionmakers should refram from ex parte communications in section 553 rulemakings seems inappropriate. As one court remarked:

[R]ule making is a vital part of the administrative process, particularly adapted to and needful for sound evaluation of policy . . . [and it] is not to be shackled, in the absence of clear and specific Congressional requirement, by importation of formalities developed for the adjudicatory process and basically unsuited for policy rule making. ${ }^{46}$

In contrast, sonie rulemaking proceedings resolve adjudicative facts and involve issues, parties, and interests generally associated with an adversarial process. In these situations, the legislative model is plainly inapplicable. For example, a Federal Commumications Commission decision regarding the licensing and assignment of a radio station cliannel to a particular applicant is hardly analogous to the process of congressional legislation. In these types of proceedings a reasonable theoretical foundation does exist for prohibiting ex parte communications and imposing other judicial procedural innovations designed to ensure basic fairness to the parties and meainngful public participation. ${ }^{47}$

\section{B. Judicial Approaches to Ex Parte Communications in Off-the- Record Proceedings.}

Prior to Home Box Office, the courts generally prohibited ex parte communications only in on-the-record proceedings and adjudications, ${ }^{48}$ as provided in the Administrative Procedure Act. ${ }^{49}$ Two early

45. ATTORNEY GENERAL's RePORT, supra note 41, at 108-09.

46. American Airlines, Inc. v. CAB, 359 F.2d 624, 629 (D.C. Cir.), cert. denied, 385 U.S. 843 (1966).

47. Additional procedural safeguards beyond the statutory minima cannot, however, be imposed on administrative agencies in the absence of coinpelling circumstances or constitutional requirements. See text accompanying notes 187-93 infra.

48. See, e.g., WKAT, Inc. v. FCC, 296 F.2d 375, 383 (D.C. Cir.) (secret ex parte contacts with "an official charged with the duty of deciding contested issues upon an open record" violated basic principles of fair play and due process in FCC comparative licensing hearing), cert. denied, 368 U.S. 841 (1961); WORZ, Inc. v. FCC, 268 F.2d 889, 890 (D.C. Cir. 1959) (allegations of ex parte pleas to Commissioner during television application proceeding required a remand to the agency for an evidentiary hearing); Massachusetts Bay Telecasters, Inc. v. FCC, 261 F.2d 55, 66-67 (D.C. Cir. 1958) (charges that parties seeking a television channel assignment used agents to influence a member of the Commission require a remand to the agency for an evidentiary hearing), cert. denied, 366 U.S. 918 (1961); Jarrott v. Scrivener, 225 F. Supp. 827, 836 (D.D.C. 1964) (ex parte contacts by State Department officials with members of a local zoning board invalidated board order granting a variance for the construction of an embassy in a residential zone). See also Camero v. United States, 345 F.2d 798, 799 (Ct. Cl. 1965). But see United Air Lines, Inc. v. CAB, 309 F.2d 238, 241 (D.C. Cir. 1962) (ex parte communications in a CAB adjudication awarding an 
cases, however, Morgan v. United States ${ }^{50}$ and Sangamon Valley Television Corp. v. United States, ${ }^{51}$ have been cited as supporting the proposition that ex parte communications are improper in off-the-record proceedings as well. 52

In Morgan the Supreine Court invalidated an order of the Secretary of Agriculture establishing minimun rates for the buying and selling of livestock at the Kansas City stockyards because the Secretary's ex parte consultations with the Departinent's Bureau of Animal Industry, which had prepared the Government's case for rate reductions, violated "fundamental requirements of fairness." 53 The Morgan holding does not, however, support an extension of the ex parte prohibition to off-the-record decisions. Although the rateinaking function can be classified as legislative, ${ }^{54}$ the Court characterized the proceedings as a "quasi-judicial"s5 inquiry and relied upon a judicial nodel of decisionmaking in rejecting the Departunent's ex parte behavior. ${ }^{56}$

The doctrine announced in Sangamon Valley is similarly limited in application. The District of Columbia Circuit held in Sangamon

airline certificate did not invalidate the agency's order because there was no showing of "corrupt tainpering with the adjudicatory process" and the communications "were placed in a public filc").

49. 5 U.S.C. $\$ 557(d)(1)$ (1976). See also note 3 supra.

50. 304 U.S. 1 (1938) (Morgan II).

51. 269 F.2d 221 (D.C. Cir. 1959), cert. denied, 376 U.S. 915 (1964).

52. Several other decisions have disapproved of ex parte communications in off-the-record proceedings, but these cases were decided on the grounds that the agencies involved ignored express statutory standards. See, e.g., Moss v. CAB, 430 F.2d 891 (D.C. Cir. 1970) (prescription of airline rates following ex parte meeting between $\mathrm{CAB}$ and airline officials without applying statutory standards or holding a meaningful public hearing as required by the Federal Aviation Act); Writers Guild of America, West, Inc. v. FCC, 423 F. Supp. 1064 (C.D. Cal. 1976) (privatc negotiation of a new programming policy with the broadcast indnstry by the FCC without providing notice or an opportunity for comment violated section 553).

In D.C. Fed'n of Civic Ass'ns v. Volpe, 459 F.2d 1231 (D.C. Cir. 1971), cert. denied, 405 U.S. 1030 (1972), the District of Columbia Circuit suggested that where agency action is not "purely legislative," ex parte communications with the agency are unacceptable. 459 F.2d at 1247. This case is of limited utility, lowever, in establishing precedent for a ban on ex parte communications in all off-the-record proceedings. Although the court did find that ex parte communications in the form of threats by several cougressmen to withhold appropriations had undermined the Secretary of Transportation's decision to approve construction of a bridge, the proceeding was inforinal agency action rather than ruleinaking and was not subject to section 553. Moreover, the court's decision was based not on due process or the Administrative Procedure Act, but on the Secretary's violation of the Federal-Aid Highways Act's, 23 U.S.C. $\$ 138$ (1976), requirement that the decision be based on certain specified and exclnsive factors. 459 F.2d at 1237-38.

53. 304 U.S. at 18-19.

54. See Peck, supra note 32, at 242.

55. Morgan v. United States, 298 U.S. 468, 480 (1936) (Morgan I).

56. The Court looked for guidance to the standards of conduct required of a judge during the course of litigation. Analogizing the consultations lere with ex parte communications between a trial judge and a plaintiff's attorney, the Court had no trouble finding a violation of due process. Morgan v. United States, 304 U.S. 1, 19-20 (1938) (Morgan II). 
Valley that an applicant's secret ex parte communications and provision of minor favors to several Federal Communications Commission commissioners after the final date for public comment violated both due process and Federal Communications Commission rules. ${ }^{57}$ The court noted that the Commission's order approving the transfer of one VHF and two UHF channels fron springfield, Illinois, to St. Louis, Missouri, pursuant to an amendnient of the Federal Conimunications Commission Table of Television Channel Assignments, was technically the product of inforinal rulemaking under the Adıninistrative Procedure Act. Nevertheless, the court viewed the Commission's decisionunaking process as a quasi-judicial "resolution of conflicting private clainus to a valuable privilege" 58 and concluded that "basic fairness require[d] such a proceeding to be carried on in the open."59 By limiting its holding to the channel allocation proceeding before it (an inforinal rulenaking proceeding ${ }^{60}$ ) the court implicitly rejected the notion that ex parte comınunications are generally incoinpatible with off-the-record administrative decisionmaking. As one commentator noted: "The peculiar fact situation and coinbination of interests and expectancies of the parties involved in [the proceeding] had converted it into an adversary proceeding to which the judicial ethic was applicable."61

Other courts that considered the permissibility of ex parte communications in off-the-record proceedings prior to the Home Box Office decision refused to hold thein improper or to inipose sanctions. ${ }^{62}$ In Van Curler Broadcasting Corp. v. United States, ${ }^{63}$ the District of Colunibia Circuit held that ex parte communications between Federal Cominunications Commission commissioners and Columbia Broadcasting Systein representatives during an infornnal rulemaking proceeding on a television channel assignment were not improper. Ignoring

57. 269 F.2d at 224-25.

58. Id. at 224.

59. Id.

60. See Action for Children's Television v. FCC, 564 F.2d 458, 475 (D.C. Cir. 1977) ("Sangainon . . . involve[d] informal rule making, as opposed to licensing-by-adjudication").

61. Peck, supra note 32, at 241.

62. See, e.g., Sterling Nat'1 Bank v. Camp, 431 F.2d 514, 516-17 (5th Cir. 1970) (counptroller's receipt of ex parte communications from several applicants was not improper in nonadversary proceeding); United States ex rel. Parco v. Morris, 426 F. Supp. 976, 982 (E.D. Pa. 1977) (administrator's receipt of ex parte communications froin congressinen was not improper in "purely legislative" informal ruleenaking proceeding setting forth deportation guidelines); Ruppert v. Washington, 366 F. Supp. 686, 689, 690 (D.D.C. 1973) (local zoning commission's receipt of ex parte communications from public agencies was not improper in "quasi-legislative" adıninistrative proceeding rezoning downtown area), aff'd, 543 F.2d 417 (D.C. Cir. 1976). See also Skokie Fed. Sav. \& Loan Ass'n v. Federal Home Loan Bank Bd., 400 F. Supp. 1016, 1020 (N.D. 11l. 1975) (court unjustified in overturning administrative decision unaffected by bias).

63. 236 F.2d 727 (D.C. Cir. 1956). 
the quasi-judicial nature of channel assignment rulemaking, ${ }^{64}$ the court noted that the ex parte interviews had not influenced the Commission's subsequent channel allocation and therefore did not violate due process. ${ }^{65}$ In fact, the contacts in question dealt with the Federal Communications Commission's general intermixture policy, which was the subject of a pending nationwide notice and comment ruleinaking proceeding. ${ }^{66}$ As a result, Van Curler has been read as upholding the legality of ex parte communications in legislative-type rulemaking proceedings. ${ }^{67}$

The same principle was affirmed by the District of Columbia Circuit only two years after Sangamon Valley in Courtaulds (Alabama) Inc. v. Dixon. ${ }^{68}$ The Courtaulds court held that the Federal Trade Commission's receipt of ex parte inaterials from an interested manufacturer did not void a Federal Trade Commission rule generically defining a certain fiber as rayon. The court specifically distinguished the Sangamon Valley doctrine, noting that the standards applicable to quasi-judicial hearings had no place in legislative rulemaking. ${ }^{69}$ More important, however, the court stated that there was "no evidence that the Commission improperly did anything in secret or gave to any interested party advantages not shared by all . . .,"70 thereby retreatimg froin a broad sanction of ex parte communications in all policy rulemakings. ${ }^{71}$

Thus, the case law prior to Home Box Office indicated that the courts would permit ex parte communications in an off-the-record proceeding unless the underlying nature of the proceeding justified the application of the judicial ethic. If a proceeding was sufficiently adversarial in character, however, the courts would disregard the Adminis-

64. See text accompanying note 58 supra.

65. $236 \mathrm{~F} .2 \mathrm{~d}$ at 730 .

66. See Peck, supra note 32, at 242; 46 Geo. WASH. L. Rev., supra note 3, at 448.

67. See $1 \mathrm{~K}$. Davis, TREATISE $\S 6: 18$, at 535 .

68. 294 F.2d 899 (D.C. Cir. 1961).

69. Id. at 904-05 n.16. Compare Action for Children's Television v. FCC, 564 F.2d 458, 476 n.29 (D.C. Cir. 1977) with Home Box Office, Inc. v. FCC, 567 F.2d 9, 56 n.124 (D.C. Cir.), cert. denied, 434 U.S. 829 (1977). The Courtaulds court's characterization of the Sangamon Valley proceeding as quasi-judicial was attacked by the District of Columbia Circuit in Home Box Office for erroneously suggesting that channel allocation proceedings were not rulemakings. The Aetion for Children's Television court interpreted the Courtaulds opinion differently, however, and stated that the opinion merely recognized that rulemakings vary widely and are sometimes highly adjudicative.

70. 294 F.2d at $904-05$.

71. The Home Box Office court seized upon this qualification in order to avoid expressly overruling Courtaulds. Nevertheless, the holding in Courtaulds that ex parte communications are not inherently impermissible in informal policy rulemaking clearly was overturned by the District of Columbia Circuit in Home Box Office. See Action for Children's Television v. FCC, 564 F.2d 458, 476 n.29 (D.C. Cir. 1977). 
trative Procedure Act's distinction between off-the-record and on-therecord proceedings and would impose adjudicative safeguards for policy or constitutional reasons. One caveat to this rule was the court's willingness to scrutinize the factual setting of the alleged ex parte contacts in order to determine if the fairness of the proceedings was in fact undermined. ${ }^{72}$ Thus, even if an off-the-record proceeding was adjudicative in character, ex parte communications were not presumed improper.

Recent decisions addressing the ex parte issue have advanced several new justifications ${ }^{73}$ for prohibiting these communications and reflect an increasing willingness to apply a judicial model of decisionmaking to agency action. The decision of the District of Colunnbia Circuit im Home Box Office, which applied a judicial model to all administrative rulemaking, ${ }^{74}$ represented a substantial departure froin the court's previous approach to the ex parte issue. Subsequent cases have, however, reinstated a case-by-case analysis of the issue, declining to prohibit ex parte commumications or to force their disclosure unless the proceeding is functionally an adjudication. ${ }^{75}$ In Action for Children's Television the court lield that a ruleniaking proceeding involving the formulation of policy revisions of general applicability ${ }^{76}$ is not inlierently "susceptible to poisonous ex parte influence."77 Subsequently,

72. The Van Curler case, for example, has been read as supporting the "proposition that ex parte contacts do not per se vitiate agency informal rulemaking action, but only do so if it appears from the administrative record under review that they may have materially influenced the action ultimately taken." Id. at 476.

73. See text accompanying notes 8-17 supra.

74. $567 \mathrm{~F} .2 \mathrm{~d}$ at 57 . The rulemaking in Home Box Office imvolved a series of policy rules regulating and limiting the content of programming offered by all television cablecasters and subscription broadcasters. 567 F.2d at 17 . With the rulemaking so characterized, there appeared to be no basis for rejecting the "patterns of legislation" that have customarily governed notice and comment rulemaking. I K. DAvis, Treatise § 6:18, at 534. Nevertheless, Judge MacKinnon attempted, in a concurring opirion, to justify the court's departure from established law by characterizing the proceeding as a rulemaking "imvolv[ing] competitive imterests of great monetary value [that] conferred preferential advantages on vast segments of the broadcast imdustry to the detriment of other competing business interests." 567 F.2d at 62 (MacKinnon, J., concurring). This distinction is unconvincing. Almost all agency rules and congressional legislation allocate portions of the public or private sector's scarce resources to one set of interests at the expense of others. This fact alone should not be sufficient to justify the application of a judicial model of decisionmaking.

75. See, e.g., Action for Children's Television v. FCC, 564 F.2d 458, 475 (D.C. Cir. 1977); Hoffman-LaRoche, Inc. v. Califano, 453 F. Supp. 900, 904 (D.D.C. 1978).

76. In Action for Children's Television, the FCC invited public comment on a series of public interest proposals establishing general standards for advertising on children's television programs. After the receipt of numerous comments on the proposals, the FCC mct with representatives of broadcast licensees and dismissed the rulemaking proceeding in exchange for industry efforts at self-regulation. 564 F.2d at 462-64.

77. Id. at 477 . 
the courts in United States Lines, Inc. v. Federal Maritime Commission $^{78}$ and in National Small Shipments Traffic Conference, Inc. v. $I C C^{79}$ held ex parte communications to be improper only after characterizing the proceedings as adjudicative. ${ }^{80}$

In its recent opinions, the District of Columbia Circuit has also continued to examime the actual effect of the alleged ex parte contacts on the agency's decisioumaking. The Home Box Office court found a factual basis for its ex parte prohibition in the Federal Communications Commission's failure to disclose the contents of its ex parte conninunications, its failure to provide such informal access to all parties, and its failure to demonstrate that the contacts did not affect the substance of the rule.81 In contrast, the court in Action for Children's Television held that the ex parte communications did not raise "serious questions of fairness"82 because ex parte meetings were held with all sides, and because the Federal Communications Commission had rational justification for its decision not to promulgate a rule. ${ }^{83}$ Several other cases have also rejected allegations of improper ex parte commumications because of the absence of a demonstrable impact on the agency proceeding. ${ }^{84}$

\section{Summary.}

This analysis of the character of off-the-record proceedings and relevant case law on ex parte communications suggests that to prohibit such communications in adjudicative agency actions, but to allow them

78. 584 F.2d 519 (D.C. Cir. 1978).

79. 590 F.2d 345 (D.C. Cir. 1978).

80. The United States Lines opinion stated: “[W]hat is involved here appears quasi-adjudicatory in nature: the agency is required to adjudicate the rights of certain named parties to an exemption from the antitrust laws." 584 F.2d at 539-40. It further suggested that the potential for bias in a Federal Maritime Commission exemption hearing is just as great as in a rulemaking that resolves "conflicting private claims to a valuable privilege ...." Id. at 539. Despite the court's focus on the adversarial nature of the proceeding before it, however, the court implied that ex parte communications are illegal in notice and comment policy rulemaking as well, thereby acknowledging the continued legitimacy of the Home Box Office approach.

In National Small Shipments the court also focused on the adjudicative nature of the off-therecord proceeding before it. The court noted: "To be sure, the ex parte commumications doctrine may not operate with identical rigor in all colorably adversarial contexts, but the adjudication contemplated in this case lies near the core described by the doctrine's rationales." 590 F.2d at 350. Thus, although the Interstate Commerce Commission tariff hearing involved was technically an informal rulemaking, the court felt justified in imposing judicial safeguards. For a detailed discussion of these opinions see note 144 infra.

81. 567 F.2d at 52-53.

82. 564 F.2d at 477.

83. Id. at $477-78$.

84. See cases cited in note 8 supra. See also Hercules Inc. v. EPA, 598 F.2d 91, 123-24 (D.C. Cir. 1978). 
in off-the-record proceedings, is not theoretically inconsistent. This analysis also suggests that the court's rejection of the legislative model of decisionmaking that has traditionally governed agency rulemaking and informal action is unjustified. As a result, the constitutional and statutory justifications recently offered by the District of Colunnbia Circuit as a basis for the prohibition of ex parte communications nuust be scrutinized.

\section{Statutory and Constitutional Arguments For Prohibiting Ex Parte Communications}

Congress has not specifically prohibited ex parte commumications in off-the-record agency proceedings. ${ }^{85}$ Consequently, courts have looked to other provisions of the Administrative Procedure Act, the provisions of agency-governing statutes, and the Constitution to find a basis for such a prohibition. Using this broad inquiry, the District of Columbia Circuit has concluded that a ban on ex parte commumications is supported by the Governinent in the Sunshine Act, ${ }^{86}$ Executive Order 11,920,87 the judicial review provisions of section 706 of the Administrative Procedure Act, ${ }^{88}$ the right of public participation granted to interested persons in section 553 of the Administrative Procedure Act, ${ }^{89}$ various "hearing" provisions of regulatory statutes, ${ }^{90}$ and the due process clause of the United States Constitution. ${ }^{91}$ Analysis of each of these justifications, however, demonstrates that the prohibition of ex parte communications is not essential.

\section{A. Implied Congressional and Executive Mandate.}

Several court decisions lave justified extending the ban on ex parte communications beyond the scope of the Admmistrative Procedure Act by invoking the open governinent policies expressed by Congress in the Government in the Sunshine Act and by the President in Executive Order 11,920. Although the Sunshine Act's ex parte provisions do not deal witll off-the-record proceedings, ${ }^{92}$ the Home Box Office court pointed to Congress' declaration that the policy of the United States is that "the public is entitled to the fullest practicable informa-

\footnotetext{
85. See note 3 supra.

86. 5 U.S.C. $\S \S 551,552,552 b, 556,557$ (1976); 39 U.S.C. $\S 410$ (1976).

87. 3 C.F.R. 121 (1977).

88. 5 U.S.C. $\$ 706$ (1976).

89. Id. $\S 553(\mathrm{c}),(\mathrm{e})$.

90. See, e.g., 46 U.S.C. $\$ 814$ (1976) (FMC); 49 U.S.C. § 316(g) (1976) (ICC).

91. U.S. CoNST. amend. V.

92. See note 3 supra.
} 

This proposed application of the Sunshine Act is plausible, ${ }^{102}$ but should be avoided for several reasons. First, it is not clear that Congress intended to use the open meetings requirements of the Sunshine Act to prohibit ex parte communications. Second, although the courts have not ruled on the construction of these provisions, they have expressed reservations regarding the applicability of the provisions to ex parte communications. ${ }^{103}$ Third, the provisions would result in inconsistent treatment of ex parte communications since sonie would be excluded from coverage because of absence of an agency quorum. ${ }^{104}$

A third authority relied upon by the District of Columbia Circuit to justify its prohibition is Executive Order $11,920,{ }^{105}$ which "prohibits ex parte contacts with members of the White House staff by those seeking to influence allocation of international air routes during the time route certifications are before the President for his approval."106 The Home Box Office court interpreted the Order as executive sanction for the prohibition of ex parte communications in quasi-legislative agency proceedings. ${ }^{107}$ In doing so, the court overextended the scope of the Order. Presidential review of international route certifications resembles an adjudication and is the culmination of a decisionmaking process that includes formal on-the-record adjudication before the Civil Aeronautics Board.108 Moreover, the Executive Order was not intended to grant any rights to private parties not otherwise required by statute. ${ }^{109}$

Contrary to the view advocated by the District of Columbia Circuit, Congress and the Administration have actually imdicated a preference for allowing ex parte communications in off-the-record agency proceedings. First, section 555(b) of the Administrative Procedure Act $^{110}$ indirectly sanctions ex parte contacts in all agency proceedings

102. See Comment, ARIz. ST. L.J. 84. The author argues that incorporating an ex parte comInunications ban in an open ineeting provision is reasonable for three reasons: (1) the Consuner Product Safety Commission has successfully done so; (2) this interpretation fills a gap in the legislation; and (3) this approach allows agencies to hold informal ineetings as long as they are open.

103. See, e.g., Action for Children's Television v. FCC, 564 F.2d 458, 473 n.26 (D.C. Cir. 1977).

104. See Comment, ARIz. ST. L.J. 85-86.

105. 3 C.F.R. 121 (1977).

106. Home Box Office, Inc. v. FCC, 567 F.2d 9, 57 (D.C. Cir.) (paraphrasing Exec. Order No. 11,920), cert. denied, 434 U.S. 829 (1977); see United States Lines, Inc. v. Federal Maritime Comm'n, 584 F.2d 519, 540 n.58 (D.C. Cir. 1978). See also 3 C.F.R. 121, § 4 (1977).

107. 567 F.2d at 57. The court claimed that the President's actions "are clearly not adjudicatory, nor even quasi-judicial." Id.

108. See Bruff, supra note 18, at 502 n.251; Nathanson 405 n.69.

109. Exec. Order No. 11,920, § 6, 3 C.F.R. 121 (1977).

110. 5 U.S.C. \& 555(b) (1976). The section provides: "So far as the orderly conduct of public business permits, an interested person may appear before an agency or its responsible employees 
including rulemakings, subject to the agency's "determination that they are consistent with the orderly conduct of public business." 111 Second, congressional leaders and the Administration failed to endorse the District of Columbia Circuit's approach to ex parte communications in the proposed "Regulatory Reform Act of 1979."112 Instead, they retained the Administrative Procedure Act's present prohibitions of ex parte communications in trial-type proceedings and left all informal rulemaking and expedited proceedings ${ }^{113}$ free of similar restrictions. Although this legislation has not yet emerged froin committee, the proposed statute may reasonably be construed as refuting the recent landmark ex parte cases.

\section{B. Meaningful Public Participation.}

Another proposition advanced to support the prohibition against, and disclosure of, ex parte commumications is that these communications foreclose the public's right of participation as set forth in section 553(c) of the Administrative Procedure Act ${ }^{114}$ or in "hearing" provisions of various regulatory statutes. ${ }^{115}$ The District of Columbia Circuit maintains that since these statutory provisions contemplate an opportumity for public response to all contentions made to the agency during the proceeding, this adversarial discussion of the issues should lead to reasoned decisionmaking. It logically follows, under this interpretation, that undisclosed ex parte commumications are improper, since they are considered by the agency without adversarial response. ${ }^{116}$

for the presentation, adjustment, or determination of an issue, request, or controversy in a proceeding, whether interlocutory, summary, or otherwise, or in connection with an agency fnnction." Id.

111. Action for Children's Television v. FCC, 564 F.2d 458, $474-75$ n.28 (D.C. Cir. 1977).

112. S. 755 , supra note 20.

113. The proposed Act dispenses with the two-tiered approach to agency procedures currently found in the Administrative Procedure Act. It establishes an intermediate level of agency procedures for "any ratemaking, rulemaking or licensing proceeding subject to section 554 of this title, other than a proceeding to withdraw, suspend, revoke, or annul a liceuse," S. 755, supra note 20, $\$ 202$, and for any other proceeding that the agency designated for expedited procedure. This intermediate proceeding would afford parties an opportunity to submit comments, but would limit formal oral argument to designated "genume and substantial disputes of fact." Id.

114. See Home Box Office, Inc. v. FCC, 567 F.2d 9, 55-56 (D.C. Cir.), cert. denied, 434 U.S. 829 (1977); Environmental Defense Fund, Inc. v. Blum, 458 F. Supp. 650, 656 (D.D.C. 1978); $c f$. Hercules Inc. v. EPA, 598 F.2d 9 I, 124-26 (D.C. Cir. 1978) (leaving open the possibility that intraagency discussions in notice and comment ruleunaking may violate the public's right to participation). But see Action for Children's Television v. FCC, 564 F.2d 458, 470-73 (D.C. Cir. 1977).

115. See National Sinall Shipments Traffic Conference, Inc. v. ICC, 590 F.2d 345, 350-51 (D.C. Cir. 1978); United States Lines, Inc. v. Federal Maritime Comm'n, 584 F.2d 519, 539-41 (D.C. Cir. 1978).

116. See, e.g., Home Box Office, Inc. v. FCC, 567 F.2d at 55. 
1. Section 553(c) of the Administrative Procedure Act. Judicial prohibition of ex parte communications is an extension of other requirements imposed by the District of Columbia Circuit to guarantee meaningful public participation in section 553 proceedings. These rulmgs require the agency to provide for a genuine exchange of views among interested persons and with the agency, ${ }^{117}$ to disclose the data and reasoning upon which a proposed decision is based, 118 to rcspond to significant poimts raised by the public, ${ }^{119}$ and to disclose the policy issues raised in the proceeding. ${ }^{20}$ Despite these precedents, the court's construction of section 553(c) is contrary to the origmal purposes of the provision and other judicial interpretations.

Section 553(c) of the Administrative Procedure Act states that an agency "shall give imterested persons an opportunity to participate in the rule inaking througli submission of written data, views, or arguments witl or witliout opportunity for oral presentation."121 It also requires the agency to issue a statement of the basis and purpose of its final rule "after consideration of the relevant matter presented." 122 Nothing in this language indicates that Congress intended to grant the public anything other than a strictly limited riglit of participation. ${ }^{123}$ Indeed, the legislative history of the Administrative Procedure Act confirms that the only purposes of the section were to enlighten the administrative agency and to protect private interests agamst uninformed or unwise action. ${ }^{124}$ Thus, even if requiring agencies to disclose all available inforination and to receive adversarial discussion of all information would make the public's participation inore "meaningful," the prohibition against ex parte communications is unwarranted. Congress granted agencies "tlıe widest latitude" to determme how to utilize the

117. See National Nutritional Foods Ass'n v. Weinberger, S12 F.2d 688, 699-700 (2d Cir.), cert. denied, 423 U.S. 827 (1975); Portland Cement Ass'n v. Ruckelshaus, 486 F.2d 375, 393-94 (D.C. Cir. 1973), cert. denied, 417 U.S. 921 (1974).

118. See Environmental Defense Fund, Inc. v. EPA, 548 F.2d 998, 1007 (D.C. Cir. 1976); Portland Cement Ass'n v. Ruckelshaus, 486 F.2d at 392-94; International Harvester Co. v. Ruckelshaus, 478 F.2d 615, 648-49 (D.C. Cir. 1973).

119. See Portland Cement Ass'n v. Ruckelshaus, 486 F.2d at 393-94.

120. See, e.g., Pillai v. CAB, 485 F.2d 1018, 1023-31 (D.C. Cir. 1973); Automotive Parts \& Accessories Ass'n v. Boyd, 407 F.2d 330, 338 (D.C. Cir. 1968).

121. 5 U.S.C. $\$ 553(c)(1976)$.

122. Id.

123. There is no indication that section 553 (c) was intended to restrict the agency to information presented during the notice and comment period by interested persons. A strictly hinited right of participation is, however, the minimum that is acceptable under section 553.

124. ATTORNEY GENERAL's REPORT, supra note 41, at 108. Nothing in the legislative history or early interpretations of the Administrative Procedure Act indicates that the right of participation included a right to know of all communications and to respond to them. See Nathanson 387. 
public's right to participation. ${ }^{125}$ As long as an agency applies the statutory minima ${ }^{126}$ under section 553 and implements procedures im substantial comphance with the provision, ${ }^{127}$ the public's right to participation is preserved.

It may be argued that if the public is denied the opportunity to respond directly to ex parte communications, the efforts of interested persons will be futile and agencies will make unreasonable decisions. The legitimacy of this fear, however, is doubtful. Professor Davis has suggested by analogy: "If Congress considcrs a bill in open committee hearings and in floor debates, would the court call the public discussions a sham if lobbyists talk to some congressmen before the votes are taken? Or is competition of the lobbyists with each other often the essence of democracy?"128 Perhaps Congress was mindful of its own practices and experiences when it established guidelines for the public's participation in off-the-record agency decisionmaking. Regardless, it is clear that Congress trusted admmistrative agencies to recognize, without judicial pronipting, ${ }^{129}$ the benefits of complete information and adversarial discussion in section 553 proceedings.

2. Statutory Hearing Provisions. An entirely different question is presented when an agency's governing statute prescribes a "hearimg" for a particular proceeding without specific reference to the Administrative Procedure Act. In these circumstances the statute and its legislative history nuust be scrutinized in order to determine whether the hearing is to be held on the record without ex parte communications under sections 554, 556, and 557 of the Administrative Procedure Act $^{130}$ and whether Congress contemplated an adversarial proceeding in which the public's right to participate requires the prohibition of ex parte communications. The first inquiry is usually easily answered. Under present Supreme Court doctrine the formal hearing require-

125. Auerbach 22.

126. See Vermont Yankee Nuclear Power Corp. v. Natural Resources Defense Council, Inc., 435 U.S. 519, 548 (1978); United States v. Florida E. Coast Ry., 410 U.S. 224, 234-38 (1973).

127. See Action for Children's Television v. FCC, 564 F.2d 458, 471 (D.C. Cir. 1977); Texaco, Inc. v. FEA, 531 F.2d 1071, 1081-82 (Emer. Ct. App.), cert. denied, 426 U.S. 941 (1976).

128. I K. Davis, Treatise $\$ 6: 18$, at 534 .

129. Professor Nathanson has concluded that there is an insufficient risk that parties will be prejudiced by a lack of adversarial discussion to justify an ex parte prohibition. See Nathanson 397-400. The need for Congress to draft its statutory provisions clearly to specify the kind of hearing procedures and public participation apphicable to agency proceedings has long been recognized. See, e.g., Hamilton, supra note 38, at 1332. Despite this problem, Congress' proposed revision of the Administrative Procedure Act retains the basic notice and comment requirements for off-the-record proceedings without reference to any right of adversarial discussion. See S. 755, supra note $20, \S 201$.

130. See 5 U.S.C. \& 557(d) (1976). 
ments and ex parte provisions of the Administrative Procedure Act do not apply unless Congress has clearly imdicated that the hearing required by statute must be a trial-type hearing on the record.131

The second inquiry is more difficult. Many statutes do not specify the type of hearing required, but instead allow the agency to structure the liearings " $\mathrm{m}$ liglit of the circumstances of the case and the nature of the issues imvolved."'132 Nevertheless, the District of Columbia Circuit has apparently decided to prohibit ex parte communications whenever the statute requires a hearing. In National Small Shipments Traffic Conference v. ICC, 133 the court stated: "[T] he statutory requirements of a hearing like the requirement of comment in notice and comment rulemaking, 'imposes certain minimum constraints on the procedures followed by the agency.' One of these constramts is the disallowance of recourse to ex parte communications."134

The court's position is based on the assumption that the hearing provisions of regulatory statutes entitle the public to an opportunity for meaningful and effective participation, ${ }^{135}$ beyond mere notice and comment, and that the ensuing need for adversarial discussion ${ }^{136}$ justifies the prohibition of undisclosed ex parte communications. The validity of this assumption as a general proposition is suspect. 137 The Supreme Court in United States v. Florida East Coast Railway ${ }^{138}$ stated that 'it cannot be doubted that a statute that requires a 'hearing' prior to rulemaking may in some circumstances be satisfied by procedures that meet only the standards of $\S 553$." 139 Thus, it can be argued 140 that if an agency's decision fits within the Administrative Procedure Act's broad definition of rulemaking, is governed by a statute that does not specify an enhanced right of public participation, and is not subject to additional due process safeguards, ${ }^{141}$ a prohibition on undisclosed ex

131. See United States v. Florida E. Coast Ry., 410 U.S. 224, 234-38 (1973); United States v. Allegheny-Ludlum Steel Corp., 406 U.S. 742, 756-58 (1972).

132. United States Lines, Inc. v. Federal Maritime Comm'n, 584 F.2d 519, 537 (D.C. Cir. 1978).

133. 590 F.2d 345 (D.C. Cir. 1978).

134. Id. at 351 (quoting United States Lines, Inc. v. Federal Maritime Comm'n, 584 F.2d at 537).

135. See United States Lines, Inc. v. Federal Maritime Comm'n, 584 F.2d at 540.

136. See text accompanying notes 114-16 supra.

137. See, e.g., 2 K. Davis, Treatise $§ 12: 16$, at 466-71. Professor Davis argues that any limitations on ex parte contacts should not apply to informal adjudication.

138. 410 U.S. 224 (1973).

139. Id. at 241.

140. See Friendly, "Some Kind of Hearing," 123 U. PA. L. REv. 1267, 1307 (1975).

141. The discussion in this section does not preclude the possibility that due process, the ultinate standard of fairness in hearings, nay independently require the prohibition of ex parte comInunications in these types of proceedings. See, e.g., Sangamon Valley Television Corp. v. United 
parte communications is not required. Conversely, when a statutory hearing provision is applicable to an informal proceeding of an essentially adjudicative nature, a reference to public participation in the regulatory statute may demand more than mere notice and comment and may justify limits on ex parte communications. ${ }^{142}$ This type of additional procedural safeguard would not be incompatible with the Supreine Court's opposition to judicial innovation expressed in $\mathrm{Ver}$ mont Yankee Nuclear Power Corp. v. Natural Resources Defense Council, Inc., ${ }^{143}$ because the court would inerely be enforcing the statutory minimum. ${ }^{144}$

States, 269 F.2d 221 (D.C. Cir. 1959). Compare Ohio Bell Tel. Co. v. Public Utils. Comm'n, 301 U.S. 292, 304-05 (1937) (due process prohibits the agency from acting on the basis of undisclosed evidence never made part of the record in a proceeding designed to force a utility to refund rate cliarges) with Bell Tel. Co. v. FCC, 503 F.2d 1250 (3d Cir. 1974) (due process did not require evidentiary learing in FCC proceedings denying request for interconnection order between connmunication common carriers), cert. denied, 422 U.S. 1026 (1975).

142. Sce Action for Children's Television v. FCC, 564 F.2d 458, 470 n.19 (D.C. Cir. 1977); $c$. Independent Bankers Ass'n v. Board of Governors of Fed. Reserve Sys., 516 F.2d 1206 (D.C. Cir. 1975) (the adjudicative clraracter of Federal Reserve decisions approving a proposal of a federal bank to engage in mortgage banking in eleven Georgia communities through a subsidiary entitled imterested clallengers to a full adjudicatory hearing with appropriate procedures, notwithstanding the lack of an "on-the-record" requirement in the Bank Holding Company Act).

143. 435 U.S. 519, 548 (1978). For a full discussion of the Vermont Yankee doctrine see text accompanying notes $187-93$ infra.

144. The result reached by the District of Columbia Circuit in National Small Shipments cannot be justified by the statutory hearing theory advanced here for several reasons. First, nothing in the Interstate Commerce Act indicated that the section $316(\mathrm{~g})$ hearing requirement conferred on interested persons the type of enhanced right of public participation that would require the prohibition of ex parte communication. 49 U.S.C. $\$ 316(\mathrm{~g})(1976)$. Second, the lnterstate Commerce Commission investigation proceeding at issue in National Small Shipments was considered "infornal rulemaking," and the Commission's decision resulted im the issuance of an imterim substantive rule. $590 \mathrm{~F} .2 \mathrm{~d}$ at $345,350-51$. Third, the focus of the proceeding was on the "validity of certain rate making principles . . . that future rate making would depend on," $i d$. at 347 , rather than on the reasonableness of past rates. See Friendly, supra note 140, at 1310 (suggestimg that a proceeding determining the reasonableness of past rates would clearly qualify as an adjudication of disputed facts in particular cases nnder the Florida East Coast doctrine). Consequently, although the court argued that an adjudicative forn of proceeding had sometimes been used in the past, $590 \mathrm{~F} .2 \mathrm{~d}$ at 350 , this fact alone did not vest any special right of participation in the public or create a statutory basis for prohibiting undisclosed ex parte communications.

In United States Lines, Inc. v. Federal Maritime Comm'n, 584 F.2d 519 (D.C. Cir. 1978), the District of Colunbia Circuit presented a more convincing statutory basis for its probibition of ex parte commumications. First, the court noted that the Federal Maritime Commission exemption proceeding at issue was not governed by the trial-type hearing requirements of sections 554, 556, and 557 of the Administrative Procedure Act or by the notice and comment rulemaking requirements of section 553. Instead, the court characterized the proceeding as quasi-adjudicatory, stating that "the agency is required to adjudicate the rights of certain nained parties to an exemption from the antitrust laws." 584 F. $2 \mathrm{~d}$ at $539-40$. Second, the court argued that the notice and liearing provisions of the Shipping Act of 1916, 46 U.S.C. $\$ \$ 801-842$ (1976), the Commission's statutory duty to determine the public interest, and the fact that the impact of the Commission's decision would extend "well beyond the immediate parties involved," $584 \mathrm{~F} .2 \mathrm{~d}$ at 540 , created a right for 


\section{Requirements of Judicial Review.}

A third rationale frequently cited by the District of Columbia Circuit in considering the permissibility of ex parte communications is that these communications unduly hamper the court's ability to engage in effective judicial review of off-the-record proceedings. ${ }^{145}$ This imposition of restraints on agency dialogue typifies recent efforts by the court to prescribe procedural rules for off-the-record agency decisionmaking. ${ }^{146}$ Whatever support previously existed for these imitiatives, the Supreine Court's decision in Vermont Yankee Nuclear Power Corp. v. Natural Resources Defense Council, Inc. ${ }^{147}$ necessitates a reevaluation of all judicially imposed restrictions not required by statute, including the court's ex parte rulings. ${ }^{148}$

the public to participate meaningfully in the decisionmaking process through adversarial discussion of all submissions and all available agency information. 584 F.2d at 539-40.

These arguments appear to provide a reasonable basis for the court's assumption that ex parte communications were improper under the learing requirements of the Shipping Act. However, the court oversimplified the nature of the proceeding involved in United States Lines. The Federal Maritime Commission's duty under section 15 of the Shipping Act is to approve all conference agreements between common ocean carriers except those that are unjustly discriminatory or unfair, detrimental to United States consumers, or contrary to the public interest. 46 U.S.C. $§ 814$ (1976). The difficulty of categorizing this function deinonstrates the "not very bright line between proceedings for the purpose of promulgating policy-type rules or standards, on the one hand, and proceedings designed to adjudicate disputed facts in particular cases on the other." Friendly, supra note 140, at 1309-10 (quoting United States v. Florida E. Coast Ry., 410 U.S. 224, 245 (1973). Although the Commission is not resolving competing claims in favor of one applicant at the expense of another, see United States Limes, Inc. v. Federal Maritime Comm'n, 584 F.2d at 539, it also is not deciding general policy. Moreover, in exercising this statutory duty, the Coinmission is free to approve conference agreements after permitting only limited notice and comment, and is not required to afford imterested parties any type of evidentiary hearing. See, e.g., Port of N.Y. Auth. v. Federal Maritime Comm'n, 429 F.2d 670 (5th Cir.), cert. denied, 401 U.S. 909 (1970); Outward Continental N. Pac. Freight Conference v. Federal Maritime Comm'n, 385 F.2d 981 (D.C. Cir. 1967).

Regardless of the label given to the proceeding in United States Lines, the Coinunission's action did not require the type of public participation that necessitates the prolibition of ex parte communications. That section 15 allegedly "recognizes the right of the public to participate in the required liearing," United States Limes, Inc. v. Federal Maritime Comm'n, 584 F.2d at 539, does not dicate a different conclusion. Ex parte communications neither foreclose the public's participation in a proceeding nor reduce the hearing to a sham. See text accompanying notes 121-28 supra.

145. See National Small Shipments Traffic Conference, Inc. v. ICC, 590 F.2d 345, 351 (D.C. Cir. 1978); United States Lines, Inc. v. Federal Maritime Comm'n, 584 F.2d 519, 541 (D.C. Cir. 1978); Home Box Office, Inc. v. FCC, 567 F.2d 9, $54-55$ (D.C. Cir. 1977). See also Hercules Inc. v. EPA, 598 F.2d 91, 124 (D.C. Cir. 1978).

146. See generally Auerbacli; Nathanson, Probing the Mind of the Administrator: Hearing Variations and Standards of Judicial Review Under the Administrative Procedure Act and Other Federal Statutes, 75 Colum. L. Rev. 721 (1975); Pedersen, Formal Records and Informal Rulemaking, 85 YALE L.J. 38 (1975); Verkuil, Judicial Review of Informal Rulemaking, 60 VA. L. Rev. 185 (1974); Wright, supra note 38 .

147. 435 U.S. 519 (1978).

148. See Bruff, supra note 18, at 503; Nathanson 407-08. 
In reviewing agency decisions involving ex parte communications under the arbitrary and capricious test, ${ }^{149}$ the District of Columbia Circuit has consistently reached three conclusions. First, the court has held that the arbitrary and capricious standard of review requires agencies to provide the courts with an administrative record that contains all of the information available to the agency at the time of the decision. ${ }^{150}$ Second, the court has determined that failure to disclose ex parte communications unduly interferes with the ability of reviewing courts to ascertain whether the agency has acted in a rational and responsible inanner and has thereby satisfied the arbitrary and capricious test. ${ }^{151}$ Third, the court has concluded that the prohibition against, and inandatory recording of, ex parte communications does not improperly restrict agency decisionmakers, even though these additional requireinents are not expressly required by statute or the Constitution. ${ }^{152}$ Each of these conclusions inerits close scrutiny.

1. Administrative Record. In drafting the Administrative Procedure Act, Congress did not conteinplate that agencies would issue rules on the exclusive basis of an administrative record. ${ }^{153}$ Therefore, the Administrative Procedure Act does not specify what information must be included in the record furnished by the agency to the court for judicial review in off-the-record proceedings. ${ }^{154}$ Following this theory, courts and commentators have generally maintained that agencies are free to formulate decisions on the basis of materials in their files, general knowledge of the industry, public comments, and administrative

149. The standard of review apphicable to off-the-record administrative rulemaking and other informal agency action has been the subject of considerable judicial dispute. Generally, however, courts have followed the Supreme Court's reasoning in Citizens to Prcserve Overton Park, Inc. v. Volpe, 401 U.S. 402, 414 (1971), and applied the arbitrary and capricious standard of section 706(A) of the Administrative Procedure Act to informal rulennaking and informal adjudication. See, e.g., Camp v. Pitts, 411 U.S. 138, 142 (1973); South Terminal Corp. v. EPA, 504 F.2d 646, 655 (1st Cir. 1974); Pedersen, supra note 146, at 48; Verkuil, supra note 146, at 206; Wright, supra note 38, at 390. But see United States v. Midwest Video Corp., 406 U.S. 649, 671 (1972) (substantial evidence); International Harvester Co. v. Ruckelshaus, 478 F.2d 615, 631 (D.C. Cir. 1973) (informcd decisionunaking process).

150. See notes 153-71 infra and accompanying text.

151. See notes 172-86 infra and accompanying text.

152. See notes $187-214$ infra and accompanying text.

153. See Auerbach 24-26; Nathanson, supra note 146, at 754-55. Both scliolars point out that the Administrative Procedure Act originally intended that rules be reviewed by the courts in enforcement or injunction proceedings, rather than on direct review. Thus, the expectation was that there would be a judicial determination of facts.

154. Section 706 of the Administrative Procedure Act does call upon the court to review "the whole record or those parts of it cited by a party . . ." 5 U.S.C. $\$ 706$ (1976). This provision was intended to ensure that the courts would decide on the basis of all evidence subinitted rather than the case presentcd by one party. Auerbach 26 . 
expertise. ${ }^{155}$ Despite this tradition, the District of Columbia Circuit relied on the Supreme Court's decision in Citizens to Preserve Overton Park, Inc. v. Volpe ${ }^{156}$ as authority for the notion that the "whole record" furnished for judicial review inust mclude all relevant views or information relied upon or known by the agency includimg any ex parte communications. ${ }^{157}$ In taking this position the court ignored its previous holding in Rodway v. Department of Agriculture 158 that the "whole record" for purposes of review under the arbitrary and capricious standard of the Administrative Procedure Act is "coinprised of comments received, hearings held, if any, and the basis and purpose stateinent."159

The District of Columbia Circuit's approach to the problem of defining a record for review is remiss in other ways as well. First, the Supreine Court cases dealing with judicial review of off-the-record administrative decisions provide nebulous authority for the primciple advocated by the court. ${ }^{160}$ These cases do not specify the required contents of the full administrative record and do not hold that the agency must adopt "specific procedures in coinpiling that record." 161 Moreover, even if the requirements of effective judicial review deinanded a comprehensive and all-encompassing record in Overton Park, not all infornial agency proceedimgs subject to the arbitrary and capricious standard of review are so restricted. Overton Park involved

155. See, e.g., Ethyl Corp. v. EPA, 541 F.2d 1, 33 (D.C. Cir.) (en banc), cert. denied, 426 U.S. 941 (1976); Consumers Union v. Consumer Prod. Safety Comm'n, 491 F.2d 810, 812 (2d Cir. 1974); Angel v. Butz, 487 F.2d 260 (10th Cir. 1973), cert. denied, 417 U.S. 967 (1974); Chrysler Corp. v. DOT, 472 F.2d 659, 669 (6th Cir. 1972); Auerbach 23-24; Verkuil, supra note 146, at 18789; Note, The Judicial Role in Defining Procedural Requirements for Agency Rulemaking, 87 HARv. L. REv. 782, 785 (1974).

156. 401 U.S. 402 (1971).

157. See United States Lines, Inc. v. Federal Maritime Comm'n, 584 F.2d 519, $539-40$ (D.C. Cir. 1978); Home Box Office, Inc. v. FCC, 567 F.2d 9, 54 (D.C. Cir.), cert. denied, 434 U.S. 829 (1977). Despite the court's insistence on a conprehensive administrative record for rulemaking, agency decisions supported by nuch less inclusive records have been affirmed regularly. See, e.g., Deutsche Lufthansa Aktiengesellschaft v. CAB, 479 F.2d 912, 916 (D.C. Cir. 1973); Chrysler Corp. v. DOT, 472 F.2d 659, 669 (6th Cir. 1972); Verkuil, supra note 146, at 205.

158. 514 F.2d 809 (D.C. Cir. 1975).

159. Id. at 817. The Rodway case involved a Department of Agriculture rulemaking regarding the allocation of food stamp coupons. In adopting its rules pursuant to the notice and comment procedures of section 553 of the Administrative Procedure Act, the Department failed to provide the court with any administrative record for judicial review in violation of the Overton Park requirements and section 706 of the Act.

160. See, e.g., Camp v. Pitts, 411 U.S. 138 (1973); Citizens to Preserve Overton Park, Inc. v. Volpe, 401 U.S. 402 (1971).

161. Byse, Vermont Yankee and the Evolution of Administrative Procedure: A Somewhat Differ. ent View, 91 HaRv. L. Rev. 1823, 1830 (1978). 
informal administrative adjudication ${ }^{162}$ pursuant to a special statutory framework requiring the Secretary of Transportation to consider specified factors, to make formal findings, and to base his decision on the information before him. ${ }^{163}$ In contrast, administrative decisionmaking under section 553 of the Administrative Procedure Act is not similarly limited in scope. The court, therefore, exceeded the authority of Overton Park by relying on that case to require an expansive administrative record. 164

Second, to interpret Overton Park as requiring "that the public record upon which . . . review is based reflect every informational input that may have entered into the decisionmaker's deliberative process"165 is contrary to prior law. ${ }^{166}$ Traditional administrative doctrine origmating in United States v. Morgan ${ }^{167}$ prohibits judicial examination of the mental processes of agency decisionmakers in the absence of a showing of bad faith or improper behavior. Thus, courts cannot ask agency decisionmakers what information, ex parte or otherwise, they considered in making their decision if the decisionmakers have provided a record for review in accordance with section 706 of the Administrative Procedure Act or in fulfillment of the requirements of a governing statute, and there is no showing of bad faith or improper behavior. In Overton Park the Court remanded the Secretary's action to the district court for plenary review and examination of the decisionmaker because the agency had failed to provide the court with any administrative record and had failed to make formal administrative findings at the same time as the decision, and because the court was potentially precluded from effective judicial review without this inquiry. ${ }^{168}$

Overton Park cannot, therefore, be read to support a judicial inquiry into ex parte communications or other agency inputs in every offthe-record proceeding. Instead, it suggests that the District of Columbia Circuit can only require the disclosure of all ex parte commumica-

162. Id.; Stewart, Vermont Yankee and the Evolution of Administrative Procedure, 91 HARV. L. REv. 1805, 1816 (1978).

163. Federal-Aid Highway Act of 1968, 23 U.S.C. $\S 138$ (1976).

164. Home Box Office, Inc. v. FCC, 567 F.2d 9, 62 (D.C. Cir.) (MacKinnon, J., concurring), cert. denied, 434 U.S. 829 (1977).

165. Action for Children's Television v. FCC, 564 F.2d 458, 477 (D.C. Cir. 1977).

166. See National Courier Ass'n v. Board of Governors of Fed. Reserve Sys., 516 F.2d 1229, 1242 (D.C. Cir. 1975); National Nutritional Foods Ass'n v. FDA, 491 F.2d 1141 (2d Cir.), cert. denied, 419 U.S. 874 (1974).

167. 313 U.S. 409, 422 (1941) (Morgan III). See also Citizens to Preserve Overton Park, Inc. v. Volpe, 401 U.S. 402, 420 (1971); Braniff Airways, Inc. v. CAB, 379 F.2d 453, 460-62 (D.C. Cir. 1967).

168. 401 U.S. at 420. 
tions under the rationale of effective judicial review if it can show that ex parte communications inherently reflect bad faith or improper behavior on the part of the agency. ${ }^{169}$ The proposition that all ex parte communications are improper is highly suspect since ex parte communications are not expressly prohibited by statute in off-the-record proceedings and are not unconstitutional. ${ }^{170}$ Moreover, it is difficult to argue that agency behavior, long considered a routine and permissible part of administrative decisionmaking in off-the-record proceedings, has suddenly beconie presumptively improper.

Third, interpreting the "whole record" for review as including ex parte communications is impractical. The logical extension of this principle would require administrators to summarize and record for comment every phone call received, every newspaper article read, and every relevant personal experience had with an industry. ${ }^{171}$ It appears nore appropriate, therefore, to defer to the line that Congress has drawn by limiting the scope of the administrative record to the items prescribed in section 553.

2. Effective Judicial Review. The second part of the court's analysis argues that when ex parte communications are not included in the administrative record provided for judicial review, the courts are unable to determine whether the agency has fulfilled its statutory function under the arbitrary and capricious standard of review. This arguinent is based on a faulty interpretation of the purposes and scope of judicial inquiry under the arbitrary and capricious test. The arbitrary and capricious test does not authorize the court to "substitute its judginent for that of the agency."172 Instead, the court's effort is limited to ensuring that the agency has not inade "a clear error of judginent" 173 and has reached its decision "in a inanner calculated to negate the dangers of arbitrariness and irrationality." 174 The agency's decision is sufficiently

169. The Home Box Office court merely hinted that ex parte communications may be in bad faith, but did not directly address the issue. 567 F.2d at 54. In contrast, another panel of the District of Columbia Circuit accorded agency decisionmakers a "strong presumption of regularity," Hercules Inc. v. EPA, 598 F.2d 91, 123-24 (D.C. Cir. 1978) (quoting Braniff Airways, Inc. v. CAB, 379 F.2d 453, 460 (D.C. Cir. 1967)), and noted that there was no evidence of bad faith on the part of the agency in rejecting an allegation that contacts between an agency judicial officer and the rulemaking staff were improper. $598 \mathrm{~F} .2 \mathrm{~d}$ at $123-24$.

170. See text accompanying notes 226-37 infra.

171. See Action for Children's Television v. FCC, 564 F.2d 458, 477 (D.C. Cir. 1977); Auerbach 50.

172. Citizens to Preserve Overton Park, Inc. v. Volpe, 401 U.S. 402, 416 (1971).

173. Id.

174. Action for Children's Television v. FCC, 564 F.2d 458, 472 n.24 (D.C. Cir. 1977). 
"reasonable"175 under this standard if the decisionmaker considered all relevant evidentiary factors and used reason to proceed from assumptions to conclusions. ${ }^{176}$

A court can review an agency decision under the arbitrary and capricious standard without the disclosure of all information available to the agency. In fact, an analysis of judicial review under this test demonstrates that ex parte communications are irrelevant to the court's examination. First, the recording of ex parte cominunications is unnecessary because of the procedural restrictions that the District of Columbia Circuit has already imposed on agencies engaged in informal proceedings. ${ }^{177}$ These procedures create an elaborate administrative record that provides a detailed explanation of the basis for the agency decision to the court. Second, regardless of these additional procedures, the failure of an agency to reveal the content of ex parte commumications to the court should not have any impact on the decision reached by the court.

Under the arbitrary and capricious standard the court is obligated to strike down agency decisions and remand them for further consideration whenever there is imsufficient evidence in the record made available to the court to support the agency's factual determination. ${ }^{178}$ Therefore, any agency that is unable to support its decision without reference to undisclosed ex parte information will be reversed upon judicial review for nraking a clear error of judgment. ${ }^{179}$ In contrast, if there is reasonable evidence in the record to justify the agency's decision, the agency's consideration of additional supporting or conflicting factual evidence through ex parte contacts is immaterial. The same reasoning may be apphied to policy determinations made by the agency in reaching its decision. Even if ex parte communications indicate that an agency decision was motivated by unarticulated pohcies or goals, this fact should not imvalidate the decision where the articulated poli-

175. Traditionally, judicial review of off-the-record proceedings was limited to determining whether there was a rational basis for the agency's decision. Verkuil, supra note 146, at 206-07. Under some formulations of the arbitrary and capricious test, however, the court's focus is on the reasonableness of the agency's decision. See Camp v. Pitts, 411 U.S. 138 (1973); United States v. Allegheny-Ludlum Steel Corp., 406 U.S. 742 (1972); Breyer, Vermont Yankee and the Courts' Role in the Nuclear Energy Controversy, 91 HARv. L. REv. 1833, 1834 (1978).

176. Wright, supra note 38, at 393-94.

177. Nathanson 392. It is also notable that although Congress has taken a number of steps in regulatory statutes to provide a better record for judicial review, it has not chosen to prohibit ex parte contacts. Id. 396.

178. See Vermont Yankee Nuclear Power Corp. v. National Resources Defense Council, Inc., 435 U.S. 519, 549 (1978); Camp v. Pitts, 411 U.S. 138, 143 (1973). See also SEC v. Chenery Corp., 318 U.S. 80 (1943).

179. Nathanson 394. 
cies are reasonable and reflect legitimate statutory considerations. ${ }^{180}$

The application of this reasoning to several of the District of Columbia Circuit's ex parte opinions is illustrative. In Home Box Office, the court could have struck down the Federal Communications Cominission's rules as arbitrary, capricious, and unauthorized by law without regard to the ex parte commumications. ${ }^{181}$ The record contaimed insufficient evidence "to support the Commission's assumption that, unless cable television programming was limited by regulation, so inuch 'siphoning' of programs from free television would occur that the public would be substantially injured."182 In contrast, if all of the Commission's factual determinations had been supported by evidence in the record, a different conclusion would have been warranted regardless of whether ex parte information was imcluded in the record. Similarly, in National Small Shipments the Commission's interim substantive rule, allowing interstate inotor carriers to base their rate structures on a new platform cost study, would not have withstood judicial review even if the Interstate Commerce Commission had not received ex parte communications. The Interstate Commerce Commission's decision was arbitrary and capricious because the available evidence did not support the vahdity of the platform cost study. ${ }^{183}$

A inore difficult example was presented by United States Lines. In that case it was iniplied that one of the actual policies underlying the Federal Maritime Commission's approval of an amendment to a joint service agreeinent between two ocean carriers liad not been placed on the record, but had emerged during ex parte communications with the Commission. ${ }^{184}$ Nevertheless, under the theory advanced here, even if the Commission was relymg upon unarticulated policy judgments, its decision should be upheld if the articulated factual and pohcy determinations were rationally supported by the evidence. In actuahty, the Commission's decision was correctly held to be arbitrary and capricious even before the court considered the ex parte commumications because the agency failed to consider all relevant factors ${ }^{185}$ and the evidence in the record did not demonstrate "a rational connection between the facts and the choices made." 186

\section{Improper Judicial Innovations. The District of Columbia Cir-}

180. Id. 395.

181. 567 F.2d 9, 18 (D.C. Cir.), cert. denied, 434 U.S 829 (1977).

182. Nathanson 394 n.47.

183. 590 F.2d 345, 352-53 (D.C. Cir. 1978).

184. 584 F.2d 519, 537-38 (D.C. Cir. 1978).

185. Id. at 532 .

186. Id. at 533 . 
cuit has also concluded that it has not improperly restrained agency decisionmaking by holding that effective judicial review requires agencies to prohibit all ex parte communications. This position is seriously undermined by the Vermont Yankee decision in which the Supreme Court rebuked the District of Columbia Circuit for ordering the Nuclear Regulatory Commission to employ rulemaking procedures not required by section 553 or the governing statute and for requiring reconsideration of a rule regulating nuclear power plant waste disposal systems. ${ }^{187}$ The Vermont Yankee Court unanimously disapproved of judicial efforts to impose special procedures on off-the-record agency proceedings, stating that "absent constitutional constraints or extremely coinpelling circumstances 'the administrative agencies should be free to fashion their own rules of procedure and to pursue methods of inquiry capable of permitting thein to discharge their inultitudinous duties." "188 At the same time, however, the Court sanctioned judicial scrutiny of the adequacy of the administrative record and authorized the reinand of agency decisions for further explanation. ${ }^{189}$

The effect of Vermont Yankee upon the District of Columbia Circuit's ex parte doctrine is unclear, but several commentators have suggested that by requiring agencies to prohibit and record ex parte commumications, the court improperly imposed an extra procedural device. ${ }^{190}$ According to this interpretation of Vermont Yankee, the District of Columbia Circuit's judicial review rationale is invalid even if undisclosed ex parte communications hamper judicial review.

Two considerations support the characterization of the ex parte restrictions as procedural requirements not required by statute. First, the District of Columbia Circuit recently acknowledged that the prohibition of ex parte communications is a judicially imposed "procedural" requireinent. ${ }^{191}$ In addition, the practical effect of the ex parte doctrine on the agency demonstrates its procedural character. Under the District of Columbia Circuit's ex parte rulings, agencies are not allowed to decide how to "best proceed to develop the needed evidence" 192 for an adequate administrative record. Instead, agencies can only reach an acceptable decision by following a process demanded by the court

187. Vermont Yankee Nuclear Power Corp. v. National Resources Defense Council, Inc., 435 U.S. 519 (1978).

188. Id. at 543 (quoting FCC v. Schreiber, 381 U.S. 279, 290 (1965) (quoting FCC v. Pottsville Broadcasting Co., 309 U.S. 134, 143 (1940)).

189. 435 U.S. at 549.

190. See Bruff, supra note 18, at 503; Nathanson 406; Comment, ARIz. ST. L.J. 95.

191. See Hercules Inc. v. EPA, 598 F.2d 91, 126 (D.C. Cir. 1978).

192. Vermont Yankee Nuclear Power Corp. v. Natural Resources Defense Council, Inc., 435 U.S. at 544 (quoting FPC v. Transcontinental Gas Pipe Line Corp., 423 U.S. 326, 333 (1976)). 
rather than by the Administrative Procedure Act or other statutes, agency decisionmakers can no longer consult with whomever they choose or receive information from any source in off-the-record proceedings, and they must place a record of any ex parte communications that do occur in the public file. Consequently, the District of Columbia Circuit has apparently assuined improperly that it, rather than the administrative agencies, should determine what procedures and practices are to be utilized by decisionmakers in off-the-record proceedings. ${ }^{193}$

In an attempt to reconcile its ex parte holdings with the Supreme Court's mandate in Vermont Yankee, the District of Colunbia Circuit lias recently advanced three arguments. First, it argued that Vermont Yankee does not require the courts to tolerate agency procedures or practices that effectively foreclose judicial review. ${ }^{194}$ In fact, however, Vermont Yankee clearly indicates that the remedy for an madequate administrative record or an unsupported decision is remand to the agency rather than the imposition of restrictions on agency practices. ${ }^{195}$ Moreover, failure to include ex parte communications in the record does not actually hamper judicial review under the arbitrary and capricious standard. 196 Second, the court argued that the prohibition of ex parte contacts does not interfere with the freedom of an agency to "structure its liearings as it finds appropriate." 197 This statement seems untenable. When an agency that previously allowed ex parte communications during its decisionmaking process is prohibited by judicial order from allowing such communications, the agency no longer freely controls its own proceeding. Finally, the court implied that procedures "mandated by relevant statutes" authorized judicial intrusion into the decisionmaking process. ${ }^{198}$ This argument is also unconvincing because the applicable statutes in the case, the Administrative Procedure Act and the Shipping Act of 1916, ${ }^{199}$ did not explicitly or implicitly prohibit ex parte communications for off-the-record proceedings.

A better argument for the District of Columbia Circuit's ex parte procedural requirements is based on the Vermont Yankee exception for

193. The legislative history of section 553 of the Administrative Procedure Act demonstrates that the need for additional procedural devices is an agency question rather than a judicial one. Byse, supra note 161 , at 1829 .

194. United States Limes, Inc. v. Federal Maritime Comm'n, 584 F.2d 519, 542 n.63 (D.C. Cir. 1978).

195. 435 U.S. at 549; Byse, supra note 161 , at 1827.

196. See text accompanying notes 177-86 supra.

197. United States Lines, Inc. v. Federal Maritime Comm'n, 584 F.2d at 542 n.63. See National Small Shipments Traffic Conference, Inc. v. FCC, 590 F.2d 345, 351 n.46 (D.C. Cir. 1978).

198. United States Lmes, Inc. v. Federal Maritime Comm'n, 584 F.2d at 542 n.63.

199. 46 U.S.C. $\$ \$ 801-842$ (1976). 
"constitutional constraints."200 Although due process standards are generally considered inapplicable to most rulemakings, ${ }^{201}$ the Vermont Yankee opinion conceded that "additional procedures inay be required in order to afford aggrieved individuals due process" 202 when an agency makes a " 'quasi-judicial' determination by which a very sinall number of persons are 'exceptionally affected, in each case upon individual grounds." "203 It is arguable, therefore, that when an off-the-record proceeding involves adversary interests, as in Sangamon Valley, the Vermont Yankee prohibition is inapplicable. ${ }^{204}$ Several of the District of Columbia Circuit's other recent ex parte decisions could also be encompassed by this constitutional exception. ${ }^{205}$

The extent to which the Court's exception for "extreinely compelling circumstances"206 apphies to the prohibition of ex parte communications is, however, clearly limited. The Court's opinion in Vermont Yankee states that "such circumstances, if they exist, are extrennely rare"207 and suggests that only "a totally unjustified departure from well settled agency procedures of long standing might require judicial correction." 208 Thus, even if the reviewing courts follow Professor Nathanson's advice and scrutinize each particular proceeding for compelling circumstances, ${ }^{209}$ it is doubtful whether there is any justification for the prohibition and disclosure of ex parte communications. For example, the District of Columbia Circuit's finding in Home Box Office that the Commission had violated its own rules by allowing ex parte communications would not satisfy the Vermont Yankee exception.210 In reaching this "technical position," 211 the Home Box Office court conceded the existence of a "long-standing Commission interpretation of its own rules to allow ex parte contacts."212 Therefore, the court could not allege "the type of longstanding and well-established practice[,] deviation from which might justify judicial intervention" under

200. 435 U.S. at $542-43$.

201. See id. at 542 n.16; United States v. Florida E. Coast Ry., 410 U.S. 224, 244-45 (1973); Bruff, supra note 18 , at 503-04.

202. 435 U.S. at 542.

203. Id. (quoting Bi-Metallic Investment Co. v. State Bd. of Equalization, 239 U.S. 441, 446 (1915)).

204. Nathanson 407.

205. See text accompanying notes 226-27 infra for further discussion of this point.

206. 435 U.S. at 543.

207. Id. at 524 .

208. Id. at 542 (footnote omitted).

209. Nathanson 408.

210. 567 F.2d at 56 n.122.

211. See Comment, ARIz. St. L.J. 77 n.45.

212. 567 F.2d at 55 n.122. 
Vermont Yankee. ${ }^{213}$ In several of the District of Columbia Circuit's subsequent ex parte cases the court did not attempt to establish "extremely compelling circumstances" because it improperly maintamed that the prohibition and recording of ex parte communications was not a procedural restriction. ${ }^{214}$

\section{Due Process.}

The final argument offered by the District of Columbia Circuit to justify the prohibition of undisclosed ex parte communications is that "fundamental notions of fairness implicit in due process"215 require agencies to conduct all proceedings including informal rulemakings and informal adjudications in the open. ${ }^{216}$ By taking this position the court has rejected traditional interpretations of the apphicability of constitutional due process to agency action and has given relevant cases a broad interpretation.

1. The Applicability of Due Process. Informal rulemaking under the Administrative Procedure Act is subject to only the most fundamental limits of due process. Although interested persons may always demand the opportunity to "establish in a judicial trial the arbitrary cliaracter" of administrative rules ${ }^{217}$ and to adjudicate disputed issues of fact after legitimate proof is offered, ${ }^{218}$ due process standards do not generally provide a basis for claiming procedural protections beyond statutory requirements.219 Nevertlieless, the broad definition of Administrative Procedure Act rulemaking 220 and the nondescript character of many other administrative decisions has led to an exception to this general principle. As the Supreme Court stated in Vermont Yan-

213. 435 U.S. at 543 n.17.

214. See text accompanying notes 190-93 supra.

215. Home Box Office, Inc. v. FCC, 567 F.2d 9, 56 (D.C. Cir.), cert. denied, 434 U.S. 829 (1977).

216. See United States Lines, Inc. v. Federal Maritime Comm'n, 584 F.2d 519, 541 (D.C. Cir. 1978); Home Box Office, Inc. v. FCC, 567 F.2d 9, 56 (D.C. Cir. 1977). See also Hercules lnc. v. EPA, 598 F.2d 91, 124-27 (D.C. Cir. 1978) (leaving open the possibility that staff contacts with agency decisionmakers in informal rulemaking are mconsistent "with fundamental notions of fairness implicit in due process"); National Small Shipments Traffic Conference, Inc. v. ICC, 590 F.2d 345, 351 (D.C. Cir. 1978) (suggesting that ex parte commumications violate basic fairness of a statutory hearing, but not explicitly finding a violation of due process).

217. Nathanson 384.

218. Pacific States Box \& Basket Co. v. White, 296 U.S. 176, 185 (1935); Borden Farm Prods. v. Baldwin, 293 U.S. 194, 209-10 (1934).

219. See, e.g., Vermont Yankee Nuclear Power Corp. v. National Resources Defense Council, Inc., 435 U.S. 519, 542 n.16 (1978); United States v. Florida E. Coast Ry., 410 U.S. 224, 244-45 (1973); Wright, supra note 38, at 379 n.15; Note, supra note 155, at 785-90.

220. See notes 39-40 supra and accompanying text. See also Note, supra note 155, at 788-89. 
kee:

In prior opinions we have intimated that even in a rulemaking proceeding when an agency is making a " "quasi-judicial" " determination by which a very small nuunber of persons are " exceptionally affected, in each case upon individual grounds," in some circumstances additional procedures may be required in order to afford the aggrieved individuals due process. ${ }^{221}$

In determining the applicability of due process strictures to a particular proceeding, the courts may choose to focus on one of the following tests: (1) the above language in Vermont Yankee, (2) Professor Davis's dichotomy between adjudicative facts and legislative facts, ${ }^{222}$ or (3) the Florida East Coast Court's distinction between "proceeding for the purpose of promulgating pohcy-type rules or standards, on the one hand, and proceedings designed to adjudicate disputed facts in particular cases on the other."223 Regardless of the test, the inquiry is highly subjective. A further difficulty arises in defining the procedures that are apphicable to a proceeding entitled to heightened due process protection. Prior to the Supreme Court's opinion in Florida East Coast, it was generally agreed that when the Constitution required a hearing, the panoply of procedures and rights contained in sections 556 and 557 of the Administrative Procedure Act automatically governed the proceeding since it would be improper to "attribute to Congress a purpose to be less scrupulous about the fairness of a hearing necessitated by the Constitution than one granted by it as a matter of expediency."224 Under Florida East Coast, however, since sections 554, 556, and 557 only apply when a statute or its legislative history expresses congressional intent for agency action "on the record after opportunity for an agency hearing," 225 the ingredients for a constitutionally adequate proceeding will vary froin case to case.

2. Ex Parte Communications and Due Process. When a proceeding is sufficiently adjudicative to warrant the due process protection of stricter agency procedural safeguards under any of the three conventional tests, ${ }^{226}$ undisclosed ex parte communications must be prohib-

221. 435 U.S. at 542 (quoting United States v. Florida E. Coast Ry., 410 U.S. 224, 242, 245 (1973) (quoting Bi-Metallic Investment Co. v. State Bd. of Equalization, 239 U.S. 441, 446 (1915)).

222. $2 \mathrm{~K}$. Davis, Treatise § 12:3.

223. 410 U.S. at 245.

224. Wong Yang Sung v. McGrath, 339 U.S. 33, 50 (1950). See also ITT v. Local 134, IBEW, 419 U.S. 428, 431, 438 (1975); Nathanson, supra note I46, at 769; Pederson, supra note 146, at 42 n.22.

225. $4 \mathrm{IO}$ U.S. at $24 \mathrm{I}$.

226. See text accompanying notes 221-23 supra. 
ited. The application of a theoretical legislative model of decisionmaking to these cases is no longer defensible, and a theoretical judicial model of decisionmaking must be applied.227 Indeed, to compare the legislative role of a congressman with that of an agency Commissioner is inappropriate under these circumstances. 228

A primary example of the application of these principles to the issue of ex parte communications is the Sangamon Valley case, ${ }^{229}$ which involved a Federal Communications Commission attempt to resolve claims to a property-like interest in the context of a television channel allocation proceeding. The court's conclusion that the proceeding was entitled to heightened due process protection and adversarial safeguards was not unreasonable. Even though the agency was technically engaged in informal rulemaking and outside the protection of due process, the task was sufficiently adjudicative to require additional fairness safeguards. ${ }^{230}$

The apparent correctness of the court's holding in Sangamon Valley does not, however, dictate a similar conclusion im otler off-the-record proceedings. Nevertheless, the District of Columbia Circuit has apparently used Sangamon Valley as a departure point for analysis, applying a test of "conflicting private claims to a valuable privilege"231 to determine the applicability of due process safeguards. For example, the Home Box Office decision stated that the principle aumounced in Sangamon Valley "so clearly governed the instant proceeding that there could be no question of the impropriety of ex parte contacts here."232 To reacli this position the court rejected the Commission's suggestion that Sangamon Valley was limited to quasi-judicial proceedings and asserted that the doctrine advanced there was applicable to all informal rulemaking. Thus, the Home Box Office court avoided scrutinizing the informal action before it and instead determined the due

227. For a discussion of these two models and their application to ex parte communications, see text accompanying notes 30-35 supra.

228. In suggesting that due process prohibited the ex parte discussions engaged in by the Secretary of Agriculture, it is difficult to determine whether the Supreme Court's ex parte communications decision in Morgan v. United States, 304 U.S. 1 (1938), can be included within this principle or whether the decision is simply wrong. See Morgan v. United States, 304 U.S. 1 (1938) (Morgan 1I). 'See also Ohio Bell Tel. Co. v. Public Utils. Comm'n, 301 U.S. 292, 304-05 (1937).

229. 269 F.2d 221 (D.C. Cir. 1959), cert. denied, 376 U.S. 915 (1964). See text accompanymg notes 57-61 supra.

230. The Vermont Yankee case nust be interpreted as prolibiting the type of extra-procedural devices required in Sangamon Valley in the absence of a constitutional justification for their imposition. See text accoinpanying notes 200-05 supra. Under the imterpretation of Sangamon Valley advanced liere, however, there is no conflict between the two cases.

231. 269 F.2d at 224.

232. Home Box Office, Inc. v. FCC, 567 F.2d 9, 56 (D.C. Cir.), cert. denied, 434 U.S. 829 (1977). 
process requirements by analogy to Sangamon Valley and recent congressional and executive branch policy expressions. ${ }^{233}$ Similarly, the District of Columbia Circuit in United States Lines justified its due process holding by asserting that the proceeding at issue was designed to guard the public's interest and had an impact beyond the immediate parties just like the informal rulemaking in Sangamon Valley. ${ }^{234}$ Moreover, the court claimed that the potential for bias was equally great in both cases, although it acknowledged that the Federal Maritime Commission proceeding did not involve a "resolution of conflicting private claims to a valuable privilege." 235

The approach used by the District of Columbia Circuit is of questionable wisdom since it avoids the fundamental and difficult questions of whether the proceeding under review should independently trigger due process protection and whether the protection should mclude restrictions on ex parte communications. It must be conceded that recent decisions prohibitimg ex parte communications have relied primarily on several detailed statutory arguments and may have added due process as an afterthought. But in light of continued resistance to further ex parte restrictions in Congress ${ }^{236}$ and the agencies, ${ }^{237}$ constitutional limitations should not be so readily imposed on the discretion of administrative agencies im these close cases.

\section{CONCLUSIONS}

The District of Columbia Circuit's prohibition of undisclosed ex parte communications in several recent cases involving off-the-record proceedings is unjustifiable. The assumption that ex parte communications are improper finds no coinpelling support in (1) the ex parte coinmunications provisions of the Administrative Procedure Act, (2) the implied intentions of Congress and the Executive Branch, (3) the pubhic's right to participation as set forth in section 553 of the Admimistrative Procedure Act and the "hearmg" provisions of various regulatory statutes, (4) the requirements of effective judicial review, or (5) the notions of basic fairness inherent in constitutional due process. The imposition of additional procedural safeguards on agency ex parte

233. See text accompanying notes $92-109$ supra.

234. United States Limes, Inc. v. Federal Maritime Comm'n, 584 F.2d 519, 540 (D.C. Cir. 1978).

235. Id. at 540,542 .

236. See text accompanying notes 110-13 supra.

237. Only three agencies have changed their procedural rules to prohibit ex parte communications in off-the-record proceedings. See note 21 supra. Many independent and executive agencies have declined to change their previous rules. For example, see Federal Communications Commission reaction referred to in note 21 supra. 
communications during off-the-record proceedings should be limited to two circumstances. First, when an informal proceeding of an essentially adjudicative nature is governed by a statutory "hearing" requirement and the statutory context demonstrates that an enhanced right of public participation was contemplated by Congress, a prohibition of ex parte communications may be required to fulfill the statute's mandate. ${ }^{238}$ Second, when an off-the-record proceeding is sufficiently adjudicative under current legal doctrimes to trigger the application of additional due process procedural safeguards, the Constitution may require a ban on ex parte communications. ${ }^{239}$

These two circumstances will converge in many of the hypothetical cases warranting the prohibition of undisclosed ex parte communications. When Congress requires an agency to act "after hearing" and indicates an intention to provide the public with an opportunity for ineaningful participation, the proceeding is likely to involve the type of decision that would be governed by due process safeguards as well. Both of these exceptional administrative circumstances are also consistent with agency decision theory presented in this Article. ${ }^{240}$ Restrictions normally characteristic of a judicial model of decisionmaking, sucl as prohibition of ex parte communications, should not be engrafted onto administrative proceedings unless necessary. The policyinaking functions of administrative agencies make the agencies distinctly different from courts, and it is inappropriate for the courts to experiment with the systein of procedures.

The District of Columbia Circuit should return to the traditional assumption that undisclosed ex parte communications are permissible in off-the-record proceedings. This approach would necessitate difficult judicial analysis in the relatively few situations involving administrative decisioninaking of an essentially adjudicative character. However, in light of Congress's continued opposition to any changes in the law governing ex parte communications, ${ }^{241}$ the alternative is continued tension and disagreement as to low administrative agencies can best fulfill their statutory duties.

238. See text accompanying notes $135-44$ supra.

239. See text accoinpanying notes 226-27 supra.

240. See text accompanying notes 30-35 supra.

241. See text accompanying notes 110-13 supra. 